\title{
Targeting IL-10 Family Cytokines for the Treatment of Human Diseases
}

\author{
Xiaoting Wang, ${ }^{1}$ Kit Wong, ${ }^{2}$ Wenjun Ouyang, ${ }^{3}$ and Sascha Rutz ${ }^{4}$ \\ ${ }^{1}$ Department of Comparative Biology and Safety Sciences, Amgen, South San Francisco, California 94080 \\ ${ }^{2}$ Department of Biomarker Development, Genentech, South San Francisco, California 94080 \\ ${ }^{3}$ Department of Inflammation and Oncology, Amgen, South San Francisco, California 94080 \\ ${ }^{4}$ Department of Cancer Immunology, Genentech, South San Francisco, California 94080 \\ Correspondence: wouyang@amgen.com; saschar@gene.com
}

\begin{abstract}
Members of the interleukin (IL)-10 family of cytokines play important roles in regulating immune responses during host defense but also in autoimmune disorders, inflammatory diseases, and cancer. Although IL-10 itself primarily acts on leukocytes and has potent immunosuppressive functions, other family members preferentially target nonimmune compartments, such as tissue epithelial cells, where they elicit innate defense mechanisms to control viral, bacterial, and fungal infections, protect tissue integrity, and promote tissue repair and regeneration. As cytokines are prime drug targets, IL-10 family cytokines provide great opportunities for the treatment of autoimmune diseases, tissue damage, and cancer. Yet no therapy in this space has been approved to date. Here, we summarize the diverse biology of the IL-10 family as it relates to human disease and review past and current strategies and challenges to target IL-10 family cytokines for clinical use.
\end{abstract}

nterleukin (IL)-10, a cytokine with pleiotropic immunosuppressive functions, is also the founding member of the IL-10 family of cytokines (Fig. 1). In addition to IL-10 itself, this group of cytokines encompasses IL-19, IL-20, IL-22, IL-24, and IL-26, which are collectively referred to as the IL-20 subfamily, as well as the more distantly related members IL-28A, IL-28B, and IL-29, also known as the interferon (IFN)- $\lambda$ family or type III IFNs (Pestka et al. 2004; Ouyang et al. 2011; Rutz et al. 2014).

IL-10 was initially described as a secreted cytokine synthesis inhibitory factor (CSIF) produced by $\mathrm{T}$ helper (Th)2 T-cell clones with the ability to inhibit the production of Th1 cyto- kines (Fiorentino et al. 1989). It has since been found that IL-10 is expressed by a wide variety of cell types of both the innate and the adaptive arms of the immune system, including macrophages, monocytes, dendritic cells (DCs), mast cells, eosinophils, neutrophils, natural killer (NK) cells, $\mathrm{CD}^{+}$and $\mathrm{CD}^{+} \mathrm{T}$ cells, and B cells (Moore et al. 2001; Ouyang et al. 2011). IL-20 subfamily cytokines are also produced mainly by immune cells, such as myeloid cells and lymphocytes (Rutz et al. 2014). Myeloid cells are the primary source for IL-19, IL-20, and IL-24 (Wolk et al. 2002). Epithelial cells, the main target cells of IL-20 family cytokines, also produce IL-19, IL-20, and IL-24 in response to cytokines

Editors: Warren J. Leonard and Robert D. Schreiber

Additional Perspectives on Cytokines available at www.cshperspectives.org

Copyright (C) 2019 Cold Spring Harbor Laboratory Press; all rights reserved; doi: 10.1101/cshperspect.a028548

Cite this article as Cold Spring Harb Perspect Biol 2019;11:a028548 
X. Wang et al.

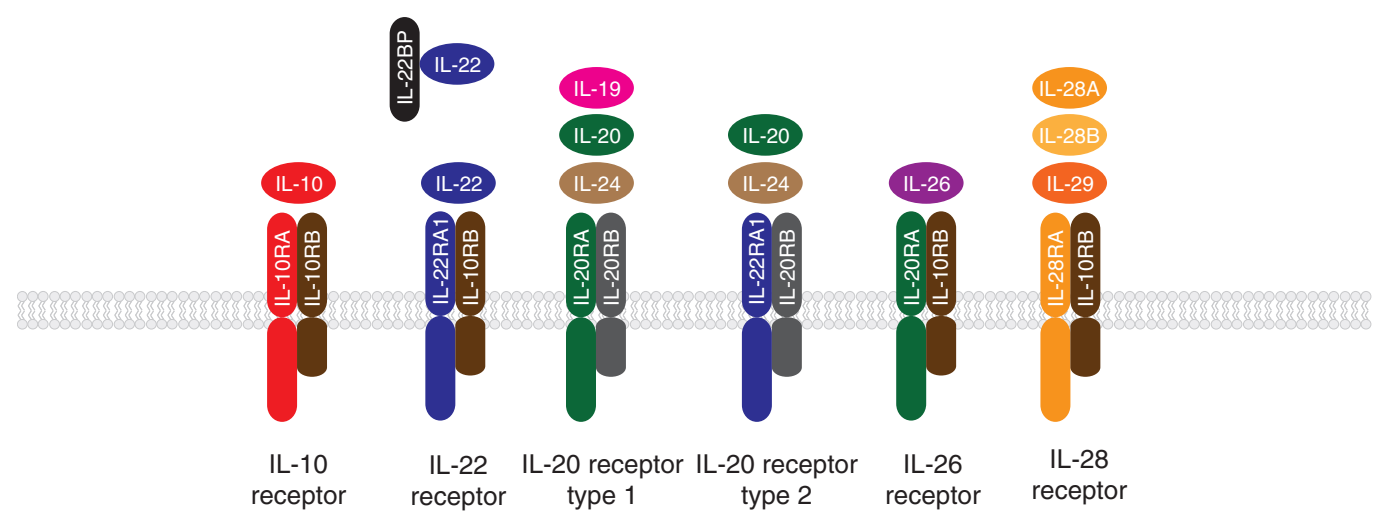

Figure 1. Interleukin (IL)-10 family cytokines and their receptors.

secreted by immune cells (Hunt et al. 2006; Sa et al. 2007; Wolk et al. 2009b). T cells are a primary source for IL-22, IL-24, and IL-26. Additionally, IL-22 is produced by various other lymphoid populations, including $\gamma \delta$-T cells, NK cells, and innate lymphoid cells (ILCs) (Rutz et al. 2013 , 2014). Finally, both leukocytes and epithelial cells are major sources of IFN- $\lambda$ family cytokines (Fig. 1) (Kotenko et al. 2003; Sheppard et al. 2003; Uzé and Monneron 2007).

Although the biological functions of the other IL-10 family cytokines are quite distinct from IL-10 itself, all family members share significant structural homology, having evolved through gene duplication. Most IL-10 family cytokines form homodimers, whereas some family members, such as IL-22, exist in a monomeric form. IL-10 family cytokines signal through heterodimeric receptors, composed of class II receptor $\alpha$ - and $\beta$-subunits (Pestka et al. 2004). The prototypical class II receptor structure consists of tandem $\beta$-sheet-rich immunoglobulin (Ig)-like domains with fibronectin type III connectivity. The $\alpha$-receptor subunits show higher affinity for the cytokine ligand than the $\beta$-subunits. Interestingly, the receptor-binding mode is virtually identical for monomeric or dimeric IL-10 family cytokines (Pestka et al. 2004).

The shared usage of common receptor subunits is a defining feature of the IL-10 cytokine family (Fig. 1). All members bind either the IL10RB or IL-20RB $\beta$-receptor subunits in combination with varying $\alpha$-subunits. IL-10 uniquely uses IL-10RA, whereas IL-19, IL-20, and IL-24 use IL-20RA as receptor $\alpha$-subunits. IL-22 binds IL-22RA1, which can also be bound by IL-20 and IL-24, collectively defining the IL-20 subfamily. IL-28A, IL-28B, and IL-29, on the other hand, use a unique IL-28RA subunit. In addition to these membrane-bound receptors, a soluble form of the IL-22 receptor (IL-22BP or IL22RA2) with homology to the extracellular domain of IL-22RA1, binds IL-22 with high affinity and blocks its activity (Ouyang et al. 2011; Rutz et al. 2014).

IL-10 family receptors signal through Janus tyrosine kinases (JAKs) and signal transducers and activators of transcription (STATs). Receptor $\alpha$-subunits are constitutively associated with Jak1, whereas Jak2 or Tyk2 are bound to the $\beta$ subunits. Ligand binding initiates recruitment and phosphorylation of STATs, which in turn form homo- and heterodimers that translocate into the nucleus to induce transcription. IL-10 and the IL-20 subfamily cytokines signal primarily through STAT3 and STAT1, whereas IL-28A, IL-28B, and IL-29 activate the ISGF3 complex (Pestka et al. 2004; Ouyang et al. 2011; Rutz et al. 2014).

Distinct receptor expression patterns drive the diverse biology of IL-10 family cytokines (Fig. 1). The IL-10RB $\beta$-subunit is ubiquitously expressed throughout the body, whereas expression of the IL-20RB $\beta$-subunit is more restricted. IL-10RA is mainly expressed on leukocytes. In contrast, IL-20 subfamily receptors show a rather 
restricted expression pattern. In particular the $\alpha$ receptor subunits, IL-20RA and IL-22RA1, are preferentially expressed on epithelial cells and fibroblasts, but absent from hematopoietic cells (Aggarwal et al. 2001; Blumberg et al.2001; Wolk et al. 2002). IL-22RA1 is highly expressed in the skin, pancreas, kidney, lung, intestine, and liver. IL-20RA is expressed in the skin, lung, ovary, testes, and placenta, and at lower levels in the intestine and liver (Rutz et al. 2013, 2014).

\section{TARGETING IL-10 FOR THE TREATMENT OF HUMAN AUTOIMMUNE DISEASES}

As a major immune regulatory cytokine, IL-10 can be produced by many leukocyte subsets and is under the control of various signal transduction pathways and transcriptional networks (Saraiva and O'Garra 2010; Rutz and Ouyang 2011, 2016). According to the expression of its receptor, IL-10 acts on many cells of the immune system (Fig. 2), where it has profound anti-inflammatory functions (Moore et al. 2001; Rutz and Ouyang 2011). IL-10 mainly targets antigen-presenting cells (APCs), such as monocytes and macrophages, and inhibits their release of proinflammatory cytokines, such as tumor necrosis factor $\alpha$ (TNF- $\alpha$ ), IL-1 $\beta$, IL-6, IL-8, granulocyte colony-stimulating factor (G-CSF), and granulocyte macrophage colony-stimulating factor (GM-CSF), as well as chemokines, including MCP1, IL-8, and IP-10 (de Waal-Malefyt et al. 1991a; Fiorentino et al. 1991; Moore et al. 2001). IL-10 also interferes with antigen presentation by reducing the expression of major histocompatibility complex (MHC)-II and costimulatory and adhesion molecules (de WaalMalefyt et al. 1991b; Willems et al. 1994; Creery et al. 1996). Furthermore, IL-10 suppresses cytokines, such as IL-12 and IL-23, which are required for $\mathrm{CD}^{+}{ }^{+} \mathrm{T}$-cell differentiation (D'Andrea et al. 1993; Schuetze et al. 2005). Similarly, IL-10 attenuates the production of inflammatory mediators, including cytokines and chemokines from neutrophils (Cassatella et al. 1993; Kasama et al. 1994). In addition, IL-10 can act directly on $\mathrm{T}$ cells to inhibit both their proliferation and cytokine production, and to induce nonresponsiveness or anergy (Groux et al. 1996). However,
IL-10 also has stimulatory effects on $\mathrm{CD}^{+} \mathrm{T}$ cells, and augments their proliferation and cytotoxic activity (Groux et al. 1998; Mumm et al. 2011). It enhances the survival of human $B$ cells and promotes B-cell proliferation (Levy and Brouet 1994; Itoh and Hirohata 1995) and contributes to the differentiation of B cells and their production and isotype switch of antibodies (Rousset et al. 1992).

\section{The Role of IL-10 in Inflammatory Bowel Disease}

Given its multiple anti-inflammatory functions, it is not surprising that IL-10 exerts essential regulatory roles in many human autoimmune diseases. Inflammatory bowel disease (IBD) comprises ulcerative colitis (UC) and Crohn's disease (CD), both of which show uncontrolled inflammation in the intestinal tract but differ in pathophysiology. Mice deficient in either IL-10 or the IL-10 receptor $\alpha$ or $\beta$ chains develop spontaneous colitis (Kühn et al. 1993), which is dependent on the presence of the intestinal microbiota and involves the up-regulation of IL-23 (Sellon et al. 1998; Yen et al. 2006). Exogenously provided recombinant IL-10 can delay and attenuate colitis development in these IL-10-deficient mice. In addition, IL-10 administration showed therapeutic value in several other colitis models (Hagenbaugh et al. 1997; Steidler et al. 2000).

IBD has a strong genetic association with the IL-10 pathway. Genome-wide association studies (GWAS) linked the IL10 locus with the susceptibility to both UC and CD (Franke et al. 2008, 2010). Furthermore, individuals carrying missense mutations in the IL10, IL10RA, or IL10RB genes develop very early-onset UC or neonatal CD (Glocker et al. 2009; Engelhardt et al. 2013; Shim et al. 2013). Restoring IL10RA or IL-10 expression by hematopoietic stem-cell transplantation rapidly alleviates clinical symptoms (Engelhardt et al. 2013).

As mentioned earlier, IL-10 represses several key proinflammatory cytokines, including TNF$\alpha$ and IL-23, which are clinically validated to participate in the pathogenesis of IBD. TNFblocking agents, including anti-TNF antibodies, 
X. Wang et al.
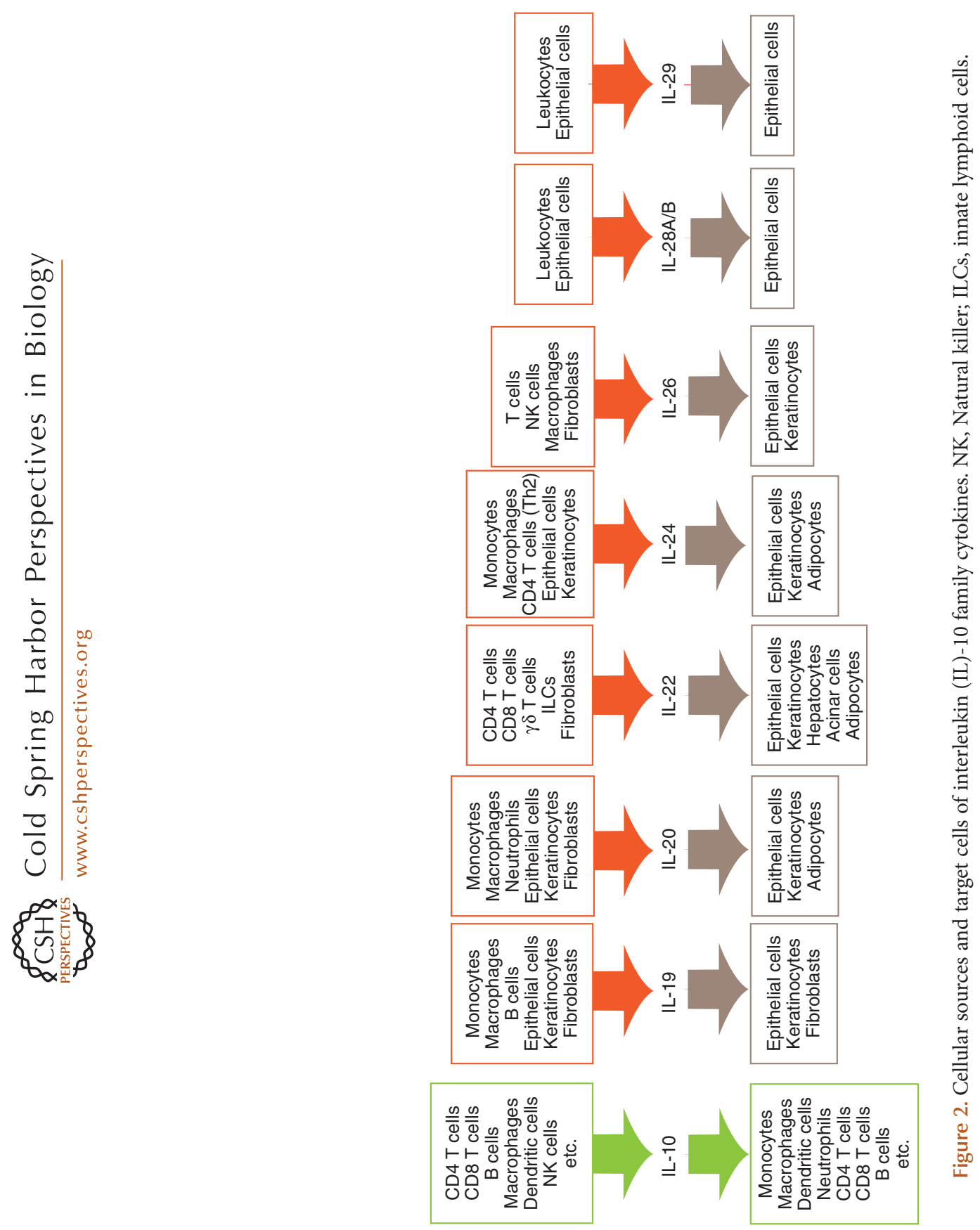
such as infliximab, adalimumab, and certolizumab, have shown good clinical efficacy in the treatment of both CD and UC, and are currently the standard of care for patients with moderateto-severe disease (Hanauer et al. 2002, 2006; Järnerot et al. 2005; Sandborn et al. 2007). Recently, an anti-IL-12/IL-23 antibody, ustekinumab, also showed promising efficacy in CD (Sandborn et al. 2008; Feagan et al. 2016). Collectively, these findings provide a strong scientific rationale for targeting IL-10 for the therapy of IBD.

Clinical Experience in Treating Inflammatory Bowel Disease with Recombinant IL-10

Recombinant IL-10 has been tested in the clinic for the treatment of IBD and other inflammatory diseases (Table 1). The first recombinant human (rhu)IL-10 (Tenovil) tested in clinical trials was produced in a genetically engineered Escherichia coli strain. This rhuIL-10 was tolerated in multiple dose toxicity studies in mice and monkey (Rosenblum et al. 2002). It was also tolerated up to $100 \mu \mathrm{g} / \mathrm{kg}$ in a single intravenous dose in healthy volunteers (Chernoff et al. 1995; Huhn et al. 1996). The pharmacokinetics of rhuIL-10 are similar to many other cytokines, with serum half-life ranging from 2.3 to $3.7 \mathrm{~h}$ (Huhn et al. 1996). A single dose of either intravenously or subcutaneously administered rhuIL-10 induced a transient increase in neutrophils and monocytes and a reduction in lymphocytes, especially at higher doses (Chernoff et al. 1995; Huhn et al. 1996, 1997). A modest decrease in circulating platelets was also observed (Huhn et al. 1997). Supporting the immunosuppressive functions of IL-10, the production of TNF- $\alpha$ and IL- $1 \beta$ was significantly reduced from lipopolysaccharide (LPS)-stimulated peripheral blood cells isolated from rhuIL-10-treated volunteers (Huhn et al. 1997). In addition, although rhuIL-10 increased the expression of Fc $\gamma$ RI on monocytes and neutrophils, the expression of activation markers IL-2R $\alpha$ and HLA-DR on T cells was inhibited (Dejaco et al. 2000).

Because rhuIL-10 was relatively well tolerated, it was tested in multiple clinical trials in IBD patients (Table 1). In the first reported trial, 46 patients with steroid refractory $\mathrm{CD}$ were treated with one of five doses of rhuIL-10 (0.5, $1,5,10$, or $25 \mu \mathrm{g} / \mathrm{kg}$ ) or placebo administered intravenously once daily for 7 days. A mild reduction in the Crohn's Disease Activity Index (CDAI) and an increase in remissions within a 3-week follow-up period were observed in the rhuIL-10-treated groups (van Deventer et al. 1997). A clinical response was observed in a trial in patients with mild-to-moderate $\mathrm{CD}$, who

Table 1. Clinical trials targeting interleukin (IL)-10

\begin{tabular}{|c|c|c|c|}
\hline Intervention & Indication & Clinical stage & Sponsor \\
\hline Tenovil (rhuIL-10) & Crohn's disease & Phase I/II N/A & $\begin{array}{l}\text { Schering-Plough } \\
\text { Research Institute }\end{array}$ \\
\hline Dekavil (F8-IL-10) & Rheumatoid arthritis & $\begin{array}{l}\text { Phase II NCT02076659 } \\
\text { Phase II NCT02270632 }\end{array}$ & Philogen/Pfizer \\
\hline Tenovil TM (IL-10) & Acute pancreatitis & $\begin{array}{l}\text { Phase II NCT00040131 } \\
\text { (terminated) }\end{array}$ & Merck Sharp \& Dohme \\
\hline IL-10 & Psoriasis & Phase II NCT00001797 & National Cancer Institute \\
\hline Prevascar (rhuIL-10) & Cicatrix, wound healing & Phase II NCT00984646 & Renovo \\
\hline $\begin{array}{l}\text { AG011 (engineered } \\
\text { Lactococcus lactis } \\
\text { secreting human IL-10) }\end{array}$ & Ulcerative colitis & Phase I/II NCT00729872 & ActoGeniX N.V. \\
\hline $\begin{array}{l}\text { AM0010: PEGylated } \\
\text { human IL-10 }\end{array}$ & $\begin{array}{l}\text { Solid tumors/pancreatic } \\
\text { cancer }\end{array}$ & $\begin{array}{l}\text { Phase I NCT02009449 } \\
\text { Phase III NCT02923921 }\end{array}$ & ARMO BioSciences \\
\hline $\begin{array}{l}\text { BT063 (antibody to } \\
\text { neutralize IL-10) }\end{array}$ & $\begin{array}{l}\text { Systemic lupus } \\
\text { erythematosus }\end{array}$ & Phase II NCT02554019 & Biotest \\
\hline
\end{tabular}

Data source: clinicaltrials.gov.

rhu, Recombinant human. 
X. Wang et al.

were treated with subcutaneous rhuIL-10 $(1,5$, 10 , or $20 \mu \mathrm{g} / \mathrm{kg}$ ) or placebo once daily for 28 days (Fedorak et al. 2000). Interestingly, in this study, only patients treated with $5 \mu \mathrm{g} / \mathrm{kg}$, but not higher doses, displayed clinical improvement. However, in a larger multicenter, double-blinded, placebo-controlled prospective study no difference in clinical remission, defined as a reduction in CDAI by more than 150 points, was observed between rhuIL-10 and placebo-treated groups (Schreiber et al. 2000). In this study, patients were subcutaneously dosed with rhuIL-10 (1, 4,8 , or $20 \mu \mathrm{g} / \mathrm{kg}$ ) or placebo daily for 28 days, and were followed for an additional 4 weeks after treatment. A significant clinical improvement (reduction of CDAI by more than 100 points) was observed only in patients who received $8 \mu \mathrm{g} /$ $\mathrm{kg}$ rhuIL-10, but not in patients who were treated with the higher dose of $20 \mu \mathrm{g} / \mathrm{kg}$. In addition, patients with high disease activity responded better (Schreiber et al. 2000). Clinical response was accompanied by a decrease in inflammatory signals as measured by nuclear factor $(\mathrm{NF})-\kappa \mathrm{B}$ activation in ileocolic biopsies. In both trials, only the intermediate, but not higher doses of rhuIL-10, induced clinical responses, suggesting a more complex biology of IL-10 in IBD. Finally, rhuIL-10 was also tested in the prevention of relapse after patients underwent a curative colon resection. In this study, both 4 and $8 \mu \mathrm{g} / \mathrm{kg} / \mathrm{d}$ did not show significant benefit in comparison to the control-treated group (Colombel et al. 2001).

Although rhuIL-10 was generally tolerated in these studies, the major side effects included a decrease in hemoglobin and thrombocyte counts, which led to significantly more withdrawals in some of the rhuIL-10-treated groups (Buruiana et al. 2010). Adverse events, such as anemia, were observed in a dose-dependent manner. Patients receiving higher doses of rhulL-10 (>4 $\mu \mathrm{g} / \mathrm{Kg})$ presented progressively and significantly decreased hemoglobin values and platelet counts (Tilg et al. 2002). These symptoms were reversible after discontinuation of therapy in all studies. The mechanism through which IL-10 induces anemia is not clear. The anemia was associated with an altered iron metabolism, as evidenced by increased serum ferritin and soluble transferrin receptor lev- els (Fedorak et al. 2000; Schreiber et al. 2000; Colombel et al. 2001). An earlier study investigating the effects of the anti-inflammatory cytokines IL-4 and IL-13 had shown that ferritin translation was enhanced by these cytokines in IFN- $\gamma$-treated activated macrophages (Weiss et al. 1997). IL-10 may act through a similar mechanism. A study investigating IL-10-induced thrombocytopenia in healthy adult volunteers suggested that IL-10 might affect platelet production indirectly through the inhibition of cytokines produced from monocytes and macrophages (Sosman et al. 2000).

As a general conclusion, systemic administration of rhuIL-10 did not result in significant clinical benefits compared with placebo groups in CD patients (Buruiana et al. 2010). The lack of efficacy may be because of an inability of IL-10 alone to sufficiently suppress all inflammatory mediators or caused by patient-to-patient variabilities in responding to exogenous IL-10. However, an important caveat in these studies is that the local IL-10 concentration in the intestine after systemic dosing may be too low to induce meaningful biological responses.

\section{Therapeutic Potential for IL-10 in Other Autoimmune Diseases}

TNF- $\alpha$ production is pathogenic in psoriasis and rheumatoid arthritis (RA), as drugs blocking the TNF- $\alpha$ pathway provide a clear therapeutic benefit in both diseases (Sfikakis 2010). Psoriasis is an inflammatory skin disease characterized by infiltration of epidermis and dermis with leukocytes that produce various inflammatory cytokines, such as TNF- $\alpha$, IL-17, and IL-22, which stimulate keratinocyte proliferation and promote epidermal hyperplasia (Nestle et al. 2009). Antibodies blocking IL-12/IL-23, TNF$\alpha$, or IL-17 have shown good efficacy for the treatment of psoriasis (Kofoed et al. 2015). IL10 might also provide therapeutic benefit in this disease, given its role in repressing proinflammatory cytokines. Indeed, in multiple clinical studies (Table 1), administration of recombinant IL-10 provided mild-to-moderate benefits for patients with psoriasis (Asadullah et al. 1998). However, further development of IL-10 
as a therapy for psoriasis was hindered by its poor in vivo pharmacokinetics and far superior efficacy of other cytokine-blocking therapies.

IL-10 has a dual role in RA, a disease characterized by synovitis associated with bone and cartilage loss, production of rheumatoid factor and autoantibodies, and systemic inflammation. Although IL-10 represses pathogenic cytokines, such as IL- 6 and TNF- $\alpha$, it also stimulates B cells and drives autoantibody production. Recombinant IL-10 has proven to be relatively safe in clinical trials in human (Chernoff et al. 1995). A new modified IL-10 that can be targeted to the site of inflammation and has better in vivo pharmacokinetics did alleviate disease severity in preclinical RA models (Trachsel et al. 2007). Currently it is being tested in RA patients (Table 1) (Galeazzi et al. 2014).

A pathogenic function for IL-10 has been proposed for type 1 diabetes (T1D) and multiple sclerosis (MS) (Asadullah et al. 2003; Saxena et al. 2015). However, given rather inconsistent results in preclinical models (Wogensen et al. 1994; Cannella et al. 1996; Nagelkerken et al. 1997; Zheng et al. 1997), targeting IL-10 in MS or T1D has not been tested in the clinic.

Systemic lupus erythematosus (SLE) is another autoimmune disease in which IL-10 might have a pathogenic role, as it is a growth factor for human B cells, promotes antibody production, class switching, and plasma cell differentiation (Rousset et al. 1992, 1995). Elevated IL-10 levels have been reported in SLE patients (Koenig et al. 2012). In a small clinical trial, six SLE patients were treated with an IL-10 blocking antibody for 21 days and followed over 6 months (Llorente et al. 2000). Although an improvement of symptoms was observed that allowed a reduction in steroid use, the lack of a control arm demands caution in interpreting the data. A placebo-controlled phase II clinical trial evaluating a neutralized anti-IL-10 antibody in SLE is currently ongoing (Table 1). In all autoimmune disorders, however, the potential risk of developing IBD when blocking the IL-10 pathway needs further evaluation.

In conclusion, although there is strong scientific rationale supporting the use of recombinant IL-10 as a therapy for various autoimmune and inflammatory diseases, the limited clinical experience thus far has not revealed clear clinical benefit.

Strategies for Improved Local Exposure and Pharmacokinetic Properties of IL-10

There are a number of possible explanations for the lack of efficacy of recombinant IL-10 therapy in patients. First, IL-10 is a pleotropic cytokine with both immune-repressive and immunestimulatory properties. For example, whereas IL-10 represses IL-12 production from macrophages and limits Th1 differentiation and IFN- $\gamma$ production induced by IL-12, it also promotes proliferation and activation of $\mathrm{CD}^{+} \mathrm{T}$ cells and their IFN- $\gamma$ production. Indeed, increased IFN$\gamma$ production has been observed in healthy volunteers and IBD patients following rhuIL-10 administration (Lauw et al. 2000; Tilg et al. 2002). By lowering the serum concentration of the administered IL-10 or by reducing its activity through protein engineering, it might be possible to overcome this problem because myeloid cells, the main therapeutic targets, have higher IL-10 receptor expression and are thus more sensitive to IL-10 (Moore et al. 2001). However, to enable this strategy, the poor pharmacokinetic properties of rhuIL-10 have to be improved to achieve sufficient coverage at lower doses. Several approaches, such as using PEGylated IL-10 or IL-10-Fc fusion proteins, are being pursued (Schwager et al. 2009; Naing et al. 2016). Another concern is that systemic delivery of rhuIL-10 will not result in sufficiently high local concentrations in the inflamed tissues. Several local delivery strategies, such as ectopic expression of IL-10 by commensal bacteria or IL-10/antibody fusion proteins, have been devised and are being tested (Table 1).

\section{Engineered Bacteria for Intestinal Delivery of IL-10}

To increase the concentration of IL-10 in the gut while minimizing systemic exposure, local delivery of IL-10 by engineered bacterial strains has been considered (Steidler et al. 2000, 2003; Miyoshi et al. 2004; Innocentin et al. 2009; del 
X. Wang et al.

Carmen et al. 2011). In this strategy, the Il10 gene is inserted into the genome of Lactococcus lactis, a widely used dairy microbe, and intragastrically administered to mice. The local delivery of mouse IL-10 substantially reduces histology scores in both dextran sulfate sodium (DSS)-induced and spontaneous colitis in IL10-deficient mice, at a significantly lower therapeutic dose (Steidler et al. 2000). This strategy provides several potential benefits. First, because oral delivery of IL-10 is not a viable option as cytokines are extremely sensitive to the acidic environment of the stomach, the engineered bacteria are able to produce recombinant IL10-locally in the intestine (Steidler et al. 2000). To further minimize degradation of IL-10 in the gastrointestinal track, an L. lactis strain expressing fibronectin-binding protein A from Staphylococcus aureus was engineered to carry an IL10-expression vector, which can efficiently deliver recombinant DNA to human epithelial cells, thereby triggering IL-10 expression in situ (Innocentin et al. 2009). IL-10 produced locally is effective in ameliorating gut inflammation in both DSS-induced and trinitrobenzene sulfonic acid (TNBS)-mediated IBD mouse models (del Carmen et al. 2014; Zurita-Turk et al. 2014). Second, this strategy minimizes systemic exposure and toxicity. For example, L. lactis is a nonpathogenic and noninvasive $\mathrm{Gram}^{+}$bacterium that survives in the digestive tract of animals or humans (Drouault et al. 1999). To control potential transgene escape into the environment, a biologically contained $L$. lactis has been developed in which the thymidylate synthase gene (thyA) has been replaced by the human IL10 gene. This strain is unable to grow in the absence of thymidine or thymine (Steidler et al. 2003). Lastly, the expression of IL-10 in bacteria can be controlled through further engineering. For example, a xylose-inducible expression system has been used to limit IL-10 production by L. lactis to the mucosal epithelium. Anti-inflammatory effects of milk fermented with this bacteria were observed in an acute TNBS-induced IBD mouse model (Miyoshi et al. 2004; del Carmen et al. 2011). Another inducible system uses stress-inducible controlled expression (SICE) based on a stressinducible promoter ( $\mathrm{pGroESL}$ ) that allows the production of murine IL-10 locally at mucosal surfaces (Benbouziane et al. 2013). Here, IL-10 is produced locally without the need for extrinsic inducers. IL-10 levels achieved through this approach result in significant protective effects as measured by gut permeability, immune responses, and gut function in a mouse IBD model (Martin et al. 2014).

In a first human trial with biologically contained L. lactis expressing human IL-10, patients with moderate-to-severe CD were dosed twice daily for 7 days (Table 1). The results showed that the approach was both safe and controllable. The genetically modified $L$. lactis could only be recovered from feces with the addition of thymidine. However, the study was conducted in a small patient population, and clinical outcomes revealed no statistically significant differences between those individuals who received the IL10-expressing strain and those patients in the control group (Steidler et al. 2003). For this strategy to succeed, several parameters need to be optimized further. A sufficient amount of IL-10 has to be produced at the site of inflammation over a prolonged period of time with minimal variations across the patient population. IL-10 needs to remain intact and functional under the harsh conditions in the gastrointestinal tract, so that biologically meaningful amounts of IL10 can cross the intestinal barrier and act on inflammatory leukocytes. The development of sensitive methods to assess the pharmacokinetics and pharmacodynamics of bacterial IL-10, both locally and systemically, will be key to the success of this approach in patients.

\section{Antibody-Conjugated IL-10 for Improved Targeted Delivery and Pharmacokinetics}

To improve the pharmacokinetic properties of IL-10 and to deliver it in a more targeted way to the site of inflammation, antibody-mediated delivery strategies have been conceived. Four antibodies, L19 (binding the extra-domain B of fibronectin), F8 (binding the extra-domain A of fibronectin), G11 (binding the extra-domain $\mathrm{C}$ of tenascin-C), and F16 (binding the extra-domain A1 of tenascin-C), which specifically recognize angiogenic but not normal tis- 
sue, were considered as fusion partners for IL-10 (Trachsel et al. 2007; Schwager et al. 2009). L19 selectively accumulates at sites of inflammation in a collagen-induced arthritis (CIA) mouse model (Trachsel et al. 2007). As a proof-of-concept, IL-10 as well as the proinflammatory cytokines IL- 2 and TNF- $\alpha$ were fused to the carboxyl terminus of a single-chain Fv fragment of L19. As expected, the L19-IL-10 fusion protein was found to be enriched at the site of angiogenesis. L19-IL-2 and L19-TNF- $\alpha$ exacerbate disease in the CIA model, whereas L19-IL-10 significantly reduces disease severity (Trachsel et al. 2007). More importantly, the repression of inflammation by L19-IL-10 is more profound than the effect mediated by a systemically distributed fusion protein of a control antibody single chain fused to IL-10 (Trachsel et al. 2007). In a comparative study, the four antibodies were used to stain synovial tissues of RA patients (Schwager et al. 2009). F8 showed the strongest staining. The corresponding IL-10 immunocytokine, F8-IL-10 (Dekavil), also showed efficacy in the CIA model (Doll et al. 2013). The combination of a murine F8-mIL-10 and a TNF-blocking muTNFR-Fc fusion protein displayed superior efficacy compared with either agent alone (Doll et al. 2013). Interestingly, F8-IL-10 also showed efficacy in endometriosis in a syngeneic mouse model and in a chronic cardiac allograft model (Schwager et al. 2011; Franz et al. 2015).

F8-IL-10 was combined with methotrexate in a preclinical toxicity study in cynomolgus monkeys. In this study, $180 \mu \mathrm{g} / \mathrm{kg}$ (equivalent to $60 \mu \mathrm{g} / \mathrm{kg}$ IL-10) of F8-IL-10 was administered subcutaneously three times a week for 8 weeks (Schwager et al. 2009). No major toxicity findings, other than transient regenerative anemia, have been reported. In pharmacokinetic measurements, about $20 \mathrm{ng} / \mathrm{ml}$ of F8-IL-10 was detected in the serum $3 \mathrm{~h}$ after subcutaneous infection with undetectable levels after $24 \mathrm{~h}$. In a phase Ib study, $24 \mathrm{RA}$ patients were dosed subcutaneously with $6 \mu \mathrm{g} / \mathrm{kg}$ to $300 \mu \mathrm{g} / \mathrm{kg}$ F8IL-10 in combination with methotrexate every week for 8 weeks. No major side effects have been reported, except for one case of progressive anemia in the $160-\mu \mathrm{g} / \mathrm{kg}$ dose group (Galeazzi et al. 2014). Among the 23 patients evaluated in this study, 15 patients achieved American College of Rheumatology (ACR)20 improvement, seven patients achieved ACR50, and three achieved ACR70 responses. Impressively, two patients experienced long-lasting remission (ACR70 maintained for more than 1 year after last dose) (Galeazzi et al. 2014). Placebo-controlled phase II clinical trials in RA patients are currently ongoing (Table 1).

\section{TARGETING IL-10 AND IL-24 FOR THE TREATMENT OF CANCER}

\section{A Potential Role for IL-10 in Cancer}

The recent success of therapies aimed at modulating the immune system to elicit antitumor immunity has completely changed the landscape of cancer therapies (Sharma and Allison 2015). Anti-PD1/PD-L1 therapies are now being considered as first-line treatment for major cancer types, such as non-small-cell lung cancer (NSCLC), at least in subsets of patients (Topalian et al. 2012, 2015; Borghaei et al. 2015; Motzer et al. 2015; Robert et al. 2015). However, many cancer patients have yet to benefit from novel cancer immunotherapies. To further unleash the immune system and promote antitumor immunity, targeting additional checkpoints, the indoleamine 2,3-dioxygenase (IDO) pathway and other strategies are being considered (Chen and Mellman 2017; Sharma et al. 2017). IL-10 has been detected in the tumor microenvironment of many cancer types, and has been correlated with poor prognosis (Nemunaitis et al. 2001; O'Garra et al. 2008; Mannino et al. 2015). Based on its strong immunosuppressive functions, especially in inhibiting IL-12 production and Th1 differentiation, IL-10 has been considered as a target for cancer immunotherapy. However, evidence for both tumor-promoting and tumor-repressing functions of IL-10 have been presented (Groux et al. 1998). On the one hand, IL-10 represses cytotoxic T-cell activation by down-regulating $\mathrm{MHC}$ expression on cancer cells and on professional APCs, thereby preventing the recognition of cancer cells by antigenspecific T cells (Adris et al. 1999; Steinbrink 
X. Wang et al.

et al. 1999). IL-10 also inhibits IL-12 production from APCs, a cytokine that strongly promotes Th1 differentiation and cytotoxicity. On the other hand, high doses of IL-10 enhance the proliferation of $\mathrm{CD}^{+}{ }^{+} \mathrm{T}$ cells and their cytotoxic activity (Groux et al. 1998; Mumm et al. 2011). Certain inflammatory cytokines and conditions may promote tissue damage and oncogenesis. For example, UC is associated with an increased risk of colon cancer (Sturlan et al. 2001; Huang et al. 2006). IL-10 may repress these inflammatory conditions, thus preventing subsequent oncogenesis. It will therefore be necessary to evaluate a potential therapeutic intervention by either inhibiting or promoting the IL-10 pathway on a case-by-case basis in specific cancer types and patient subpopulations.

The role of IL-10 in various cancer models has been examined since it was first discovered (Asadullah et al. 2003; Vicari and Trinchieri 2004). In an IL-2 promoter-driven IL-10 transgenic mouse model, elevated expression of IL-10 results in failure to control an immunogenic tumor, an effect that can be reversed by administering an anti-IL-10 antibody (Hagenbaugh et al. 1997). Similarly, IL-10-deficient mice are resistant to UV-induced skin carcinogenesis, a finding that is correlated with a potent Th1 response in these mice (Loser et al. 2007). In contrast, in a chemically induced skin carcinoma model, IL-10 deficiency results in significantly increased tumor burden and accelerated mortality (Mumm et al. 2011). In tumor-bearing mouse mammary tumor virus-polyoma middle T oncogene (MMTV-PyMT) mice, antibody blockade of IL-10RA combined with paclitacel chemotherapy provides significant therapeutic benefit (Ruffell et al. 2014). On the other hand, the administration of PEGylated murine IL-10 in both a Her2 transgenic mouse breast cancer model and in a squamous cell carcinoma model can suppress tumor growth, supporting the rationale for IL-10 therapy in these cancers (Mumm et al. 2011). IL-10 induces antigen-specific $\mathrm{CD}^{+}{ }^{+} \mathrm{T}$-cell responses and increases IFN- $\gamma$ production from these cells. Furthermore, the antitumor activity of PEGylated IL-10 is dependent on IL-10 receptor expression on $\mathrm{CD}^{+} \mathrm{T}$ cells, further supporting the notion of these cells being direct IL-10 targets in this setting (Emmerich et al. 2012).

\section{Clinical Experience with IL-10 Therapies in Cancer}

Based on the potential antitumor effects of IL10, a PEGylated human IL-10 (PEG-rhuIL-10) was engineered for clinical use (Naing et al. 2016). Whereas PEG-rhuIL-10 inhibited IFN$\gamma$ production in peripheral blood mononuclear cells (PBMCs) in vitro, it stimulated IFN- $\gamma$ secretion from $\mathrm{CD}^{+} \mathrm{T}$ cells. PEG-rhuIL-10 also promoted perforin and granzyme B production from $\mathrm{CD}^{+} \mathrm{T}$ cells, supporting its role in enhancing cytotoxicity (Naing et al. 2016). This molecule has recently been tested in clinical trials in cancer patients (Table 1). The PEGrhuIL-10 has a prolonged half-life and exposure compared with rhuIL-10. In this study, patients were treated with one of six different doses (1, $2.5,5,10,20$, and $40 \mu \mathrm{g} / \mathrm{kg}$ ) of PEG-rhuIL- 10 . In addition to increased IFN- $\gamma$ levels in the serum, elevated IL-18 and reduced TGF- $\beta$ levels were observed in treated patients, supporting the immune stimulatory function of this molecule in vivo. Interestingly, some partial clinical responses have been observed in this small cohort of patients (Naing et al. 2016). A phase III clinical trial investigating PEG-rhuIL-10 in combination with FOLFOX in metastatic pancreatic cancer patients is currently ongoing (Table 1).

\section{Antitumor Activity Elicited by Ectopic Expression of IL-24 in Cancer Cells}

IL-24 has been ascribed unique antitumor activity when intrinsically expressed in tumor cells. Although the primary cellular sources of IL-24 include T cells and myeloid cells (Fig. 2), IL-24 was first discovered with elevated expression levels in terminally differentiated human melanoma cells treated with recombinant IFN- $\beta$ and the protein kinase $\mathrm{C}(\mathrm{PKC})$ activator mezerein (Jiang et al. 1995). Enhanced IL-24 expression causes an irreversible growth arrest and suppression of tumorigenic properties. Similar results were obtained in a variety of human cancer cells, 
Targeting IL-10 Family Cytokines to Treat Diseases

including lung, colorectal, breast, and prostate cancer (Emdad et al. 2009; Whitaker et al. 2012). Interestingly, IL-24 is also readily induced in some normal epithelial and fibroblast cells with insignificant effects on growth and survival (Jiang et al. 1996; Su et al. 1998). IL-24 was categorized as an IL-10 cytokine family member based on its conserved genomic structure, chromosome localization, and cytokine-like properties (Caudell et al. 2002; Sauane et al. 2003). It shares the same receptor complex with IL-20 (Rutz et al. 2014). However, no direct antitumor effects have been reported for any other family member. Only ectopic expression of IL-24 in tumor cells, but not its addition to the culture media, shows antitumor activity in cultured cancer cells (Whitaker et al. 2012). Several potential mechanisms for these surprising findings have been discussed, including endoplasmic reticulum stress, the unfolded protein response, apoptosis, autophagy, and the production of reactive oxygen species, seemingly independent of IL-24 receptor signaling (Whitaker et al. 2012). However, whether the antitumor activities of IL-
24 are linked to its properties as a cytokine is still a matter of debate (Kreis et al. 2007, 2008).

The therapeutic potential of IL-24 for cancer treatment has been evaluated in clinical trials (Table 2). Efficacy was observed in a phase I/II clinical trial in patients with multiple advanced cancers following intratumoral injection of INGN 241, an adenovirus expressing IL-24 (Cunningham et al. 2005; Tong et al. 2005). Up to $80 \%$ of tumor cells at the injection sites showed positive terminal deoxynucleotidyl transferase dUTP nick end labeling (TUNEL) staining, and $67 \%$ of tumors showed reduced Ki-67 staining postinjection. A transiently elevated level of $\mathrm{CD}^{+} \mathrm{T}$ cells and cytokines IL-6, IL-10, and TNF- $\alpha$ were noticed in peripheral blood, consistent with increased tumor apoptosis. The intratumoral injection of INGN 241 was well tolerated with some mild side effects, including pain and erythema at the injection sites. Only one of the patients suffered from grade 3 serious adverse events (SAEs) and discontinued the trial. It is unclear, however, whether the observed activity in this study was mediated solely

Table 2. Clinical trials targeting interleukin (IL)-20, IL-22, and IL-24

\begin{tabular}{|c|c|c|c|}
\hline Intervention & Indication & Clinical stage & Sponsor \\
\hline $\begin{array}{l}\text { NNC109-0012: anti- } \\
\quad \text { IL-20 }\end{array}$ & Rheumatoid arthritis & $\begin{array}{l}\text { Phase I NCT00818064 } \\
\text { Phase I NCT01038674 } \\
\text { Phase II } \\
\text { NCT01282255 } \\
\text { NCT01636817 (terminated) } \\
\text { NCT01636843 (terminated) } \\
\text { Phase I } \\
\text { NCT01261767 (terminated) }\end{array}$ & Novo Nordisk A/S \\
\hline $\begin{array}{l}\text { F-652: } \\
\text { IL-22 IgG2-Fc }\end{array}$ & $\begin{array}{l}\text { Alcoholic hepatitis } \\
\text { Acute GVHD }\end{array}$ & $\begin{array}{l}\text { Phase I/II NCT02655510 } \\
\text { Phase I/II NCT02406651 }\end{array}$ & $\begin{array}{l}\text { Mayo Clinic Generon } \\
\text { (Shanghai) }\end{array}$ \\
\hline ILV-094: anti-IL22 & $\begin{array}{l}\mathrm{HV} \\
\mathrm{HV} \\
\text { Psoriasis } \\
\text { Atopic dermatitis } \\
\text { Rheumatoid arthritis }\end{array}$ & $\begin{array}{l}\text { Phase I NCT00434746 } \\
\text { Phase I NCT00447681 } \\
\text { Phase I NCT00563524 } \\
\text { Phase II NCT01941537 } \\
\text { Phase II NCT00883896 }\end{array}$ & $\begin{array}{l}\text { Rockefeller University } \\
\text { Pfizer }\end{array}$ \\
\hline ILV-095: anti-IL22 & $\begin{array}{l}\mathrm{HV} \\
\mathrm{HV} \\
\text { Psoriasis }\end{array}$ & $\begin{array}{l}\text { Phase I NCT00822835 } \\
\text { Phase I NCT00822484 } \\
\text { Phase I NCT01010542 } \\
\quad \text { (terminated) }\end{array}$ & Pfizer \\
\hline INGN 241 (Ad-mda-7) & Melanoma & Phase II NCT00116363 & Introgen Therapeutics \\
\hline
\end{tabular}

Data source: clinicaltrials.gov.

GVHD, Graft-versus-host disease. 
X. Wang et al.

by IL-24, or by the immune response elicited by the virus, or both.

\section{THE IL-20 SUBFAMILY OF CYTOKINES IN HUMAN DISEASE}

IL-20 subfamily cytokines mainly facilitate the communication between leukocytes and epithelial cells (Fig. 2), where they function to enhance innate defense mechanisms, wound healing, and tissue repair at epithelial surfaces (Rutz et al. 2014). Although it is evident how these functions can be beneficial to the host during infections, a clear role in host defense has only been established for IL-22. IL-22 is indispensable during infections with extracellular pathogens such as Citrobacter rodentium, Klebsiella pneumonia, or yeast at mucosal surfaces (Ouyang et al. 2011; Rutz et al. 2013; Eidenschenk et al. 2014). Recent studies also reveal important functions of IL-22 in shaping intestinal homeostasis and commensal communities (Sonnenberg et al. 2011). However, IL-20 subfamily cytokines have been widely studied for their roles in inflammation and autoimmunity, most prominently in the context of skin inflammation, with well-defined pathogenic roles in psoriasis, atopic dermatitis (AD) (Sa et al. 2007; Ouyang 2010; Sabat et al. 2013), and RA. Exciting new approaches are aimed at harnessing the tissue-protective and wound-healing functions of IL-22 for the treatment of IBD and diabetic foot ulcer (DFU).

\section{Role of IL-20 Subfamily Cytokines in Psoriasis}

As briefly discussed above, psoriasis is a chronic inflammatory disease of the skin characterized by abnormal keratinocyte differentiation and proliferation, leukocyte infiltration into the dermis and epidermis, and increased dilation and growth of blood vessels. The cross talk between keratinocytes and leukocytes is essential during the pathogenesis of psoriasis. Various leukocytes, including $\mathrm{T}$ cells, neutrophils, DCs, and macrophages, infiltrate into the skin and contribute to inflammation. IL-19, IL-20, IL-22, and IL-24 are expressed in psoriatic but not in healthy skin (Rømer et al. 2003; Wolk et al. 2004; Otkjaer et al. 2005). More importantly, the receptors for IL-20 subfamily cytokines are highly expressed on keratinocytes (Sa et al. 2007). T cells appear to be the major source of IL-22 in psoriatic skin lesions. T cells isolated from skin lesions produce much higher levels of IL-22 than T cells in circulation (Boniface et al. 2007). In addition, T-cell clones generated from psoriatic tissue are largely CCR6 ${ }^{+}$ IL-22 ${ }^{+}$, presumably Th17 cells or Th22 cells (Pène et al. 2008; Kagami et al. 2010). Myeloid cells and keratinocytes themselves are potential sources of IL-19, IL-20, and IL-24 (Fig. 1) (Sa et al. 2007; Tohyama et al. 2009; Wolk et al. 2009b).

The role for IL-20 subfamily cytokines in psoriatic skin inflammation has been extensively studied in preclinical models in mice. Transgenic mice that ectopically express IL-20, IL-22, or IL-24 develop skin lesions and histological features similar to those seen in human psoriasis (Blumberg et al. 2001; Wolk et al. 2009a; He and Liang 2010). Direct injection of IL-23 induces ear thickening, acanthosis, and dermal infiltrates, similar to some features in psoriatic skin (Kopp et al. 2003; Chan et al. 2006; Zheng et al. 2007), which are dependent on IL-22 and other IL-20 family cytokines. In addition, injection of IL-22 into the skin of normal mice induces S100 and $\beta$-defensin, as well as keratinocyte hyperplasia (Ma et al. 2008), whereas neutralization of IL-22 or IL-23 prevents psoriasis-like symptoms induced by the transfer of $\mathrm{CD}^{+} \mathrm{CD} 45 \mathrm{RB}^{\mathrm{hi}}$ CD25- cells into severe combined immunodeficiency (SCID) mice (Ma et al. 2008). Furthermore, the treatment of immunodeficient mice engrafted with human psoriatic skin with blocking antibodies to IL-20 or IL-22 resolves the psoriasis condition (Stenderup et al. 2009; Perera et al. 2014).

IL-20 subfamily cytokines induce several factors that either promote or sustain psoriatic lesions. All IL-20 subfamily members, except IL-26, induce the expression of various antimicrobial peptides, including S100 family genes and $\beta$-defensin family genes (Boniface et al. 2005; Liang et al. 2006; Wolk et al. 2006; Sa et al. 2007). Furthermore, the IL-20 subfamily 
Targeting IL-10 Family Cytokines to Treat Diseases

cytokines, especially IL-22, regulate genes in keratinocytes and fibroblasts involved in tissue remodeling, including proteases and extracellular matrix proteins, such as MMP1, MMP3, kallikrienes, marapsin, and platelet-derived growth factor (PDGF) (Boniface et al. 2005; Wolk and Sabat 2006; Sa et al. 2007; Li et al. 2009). IL-20 subfamily cytokines promote the re-epithelialization process by acting on epidermal keratinocytes, partly through the induction of keratinocyte growth factor (KGF) and epidermal growth factor (EGF). IL-20 subfamily cytokines also activate proinflammatory responses through the induction of chemokines and cytokines from keratinocytes, including CXCL1, CXCL5, and CXCL7 (Boniface et al. 2005; Sa et al. 2007). The effects of IL-20 subfamily cytokines can be further synergized by other proinflammatory cytokines, such as IL-17A, TNF- $\alpha$, or IFN- $\gamma$ (Liang et al. 2006; Tohyama et al. 2009; Guilloteau et al. 2010), suggesting that IL-20 subfamily cytokines in conjunction with other proinflammatory cytokines orchestrate the pathogenesis of psoriasis.

\section{Clinical Experience with Targeting IL-20 Subfamily Cytokines in Psoriasis}

Despite the convincing preclinical data suggesting a disease-promoting role for IL-20 subfamily cytokines in psoriasis, neutralizing antibodies targeting either IL-20 or IL-22 did not advance in clinical trials (Table 2). A randomized, placebo-controlled, phase I/IIa dose-escalation trial was conducted to evaluate a fully human IgG4 anti-IL-20 antibody in patients with moderateto-severe stable chronic plaque psoriasis. However, the trial's expansion phase was terminated early owing to an apparent lack of Psoriasis Area and Severity Index (PASI) improvement (Gottlieb et al. 2015). Similarly, early-stage clinical trials evaluating two anti-IL22 antibodies (fezakinumab, ILV-095) were ended, presumably because of lack of efficacy. Although the failure of these trials may be simply a result of redundant functions of IL-20 and IL-22, the clinical data suggest that IL-20 subfamily cytokines might not be the key engine driving the inflammatory cascade in psoriasis.
Targeting IL-22 for the Treatment of Atopic Dermatitis

Atopic dermatitis (AD) is the most common inflammatory skin disease, affecting up to $25 \%$ of children and up to $3 \%$ of the adult population (Williams 2005; Montes-Torres et al. 2015). AD is characterized by itchy, red, and flaky lesions that often occur on bending sides of the limbs. The lesions are infiltrated with immune cells in the dermis and epidermis. Acanthosis, fibrosis, and collagen deposition are observed during the chronic phase. IL-22 has been shown to contribute to the epidermal barrier dysfunction in $\mathrm{AD}$, and also seems to be responsible for the characteristic epidermal hyperplasia (Nograles et al. 2009; Gittler et al. 2012). IL-22 is highly expressed in the affected skin of patients (Wolk et al. 2004). In contrast to psoriasis, the expression of IL-22 in AD is mainly derived from Th22 cells and from IL-22-producing $\mathrm{CD}^{+}$cells (Nograles et al. 2009). The role of IL-22 in the development and maintenance of $\mathrm{AD}$ needs further exploration. However, a phase II clinical trial with an anti-IL-22 antibody (ILV-094) in patients with moderate-to-severe AD is currently ongoing (Table 2). Data from this study is not yet available.

\section{Role of IL-20 Subfamily Cytokines in Rheumatoid Arthritis}

IL-20 subfamily cytokines have been studied extensively for their role in RA. All family members are up-regulated in synovial fluid of RA patients (Ikeuchi et al. 2005; Hsu et al. 2006; Kragstrup et al. 2008; Sakurai et al. 2008; Alanärä et al. 2010; Corvaisier et al. 2012). The corresponding receptors are expressed in synovial tissues (Ikeuchi et al. 2005; Kragstrup et al. 2008; Sakurai et al. 2008; Corvaisier et al. 2012). Increased frequencies of IL-22- and IL-26-producing Th17 cells and Th22 cells are found in peripheral blood and joints of RA patients (Pène et al. 2008; Shen et al. 2009; Leipe et al. 2011; Zhang et al. 2012). IL-19, IL-20, and IL-22 are thought to be pathogenic in RA owing to their ability to enhance the proliferation of synovial cells and to induce proinflammatory cytokines 
X. Wang et al.

and chemokines, including IL-6, IL-8, and CCL2 (Ikeuchi et al. 2005; Sakurai et al. 2008). Additionally, IL-20 promotes neutrophil chemotaxis (Hsu et al. 2006).

Preclinical data further support a pathogenic role of IL-20 subfamily cytokines in arthritis. Blockade of IL-19 or the administration of a soluble IL-20RA attenuates disease in collagen-induced arthritis in rats (Hsu et al. 2006, 2012).

Based on these data, a neutralizing anti-IL20 antibody has been evaluated in a phase II clinical study in patients with active RA (Table 2). Sixty-seven patients with RA received either anti-IL-20 (3 mg/kg per week, subcutaneously) or a placebo over 12 weeks with a 13-week follow-up. A significant proportion of patients with seropositive RA receiving anti-IL-20, compared with those receiving placebo, achieved treatment responses according to the American College of Rheumatology 20\% (ACR20) (59\% vs. 21\%), ACR50 (48\% vs. 14\%), and ACR70 (35\% vs. $0 \%$ ) levels of improvement (Šenolt et al. 2015).

An elevated plasma concentration of IL-22 is associated with disease severity and progression of erosive RA in patients (Leipe et al. 2011; Zhang et al. 2011; da Rocha et al. 2012), suggesting that IL-22 blockade might be equally efficacious in the treatment of RA. However, preclinical arthritis models paint a more complicated picture. Blockade of IL-22 with neutralizing antibodies before disease onset increases the incidence and severity of collagen-induced arthritis in mice, whereas treatment after disease onset is beneficial (Justa et al. 2014). In a different model, anti-IL-22 reduces inflammation and bone erosion, but does not affect overall arthritis severity (Marijnissen et al. 2011).

Nonetheless, a neutralizing anti-IL-22 antibody (ILV-094) has been evaluated in a phase II clinical trial for the treatment of RA (Table 2), but the results of the study have not been published to date.

\section{Therapeutic Potential for IL-22 in Inflammatory Bowel Disease}

Genetic studies in IBD not only revealed alterations in pathways regulating inflammation, such as the IL-10 pathway, but also showed a strong link between defects in epithelial innate defense and integrity and disease onset (Xavier and Podolsky 2007; Kaser et al. 2010). The IL-22 receptor, but not the IL-20 receptor, is highly expressed in the gastrointestinal tract (Zheng et al. 2008; Wang et al. 2014), suggesting a predominant role for IL-22 in regulating intestinal epithelial cells during inflammation and host defense (Ouyang 2010). Although more pronounced in CD, UC patients also show increased numbers of IL-22-producing cells in affected tissues (Andoh et al. 2005; Yu et al. 2013). Sources of IL-22 in the intestine comprise Th cells and innate cells, such as Th17, Th22, ILCs, and NK22 cells (Andoh et al. 2005; Geremia et al. 2011). More importantly, changes in IL-22 expression occur during acute phases of disease. In UC patients, a significant reduction in $\mathrm{IL}-22^{+} \mathrm{CD}^{+} \mathrm{T}$ cells has been observed in actively inflamed tissues compared with normal tissues from UC patients or from healthy controls (Leung et al. 2013). The reduction in IL-22

Figure 3. Therapeutic potential of interleukin (IL)-22-Fc fusion protein in inflammatory bowel disease and diabetic foot ulcer patients. (A) In inflammatory bowel disease, severe epithelium damage and uncontrolled microbiota result in chronic inflammation in the gut. Systemic administration of IL-22-Fc is thought to promote epithelial cell regeneration, stimulate the production of antimicrobial peptides to control the microbiota, enhance the mucin production to restore mucus layer, and boost chemokine secretion to recruit immune cells for host defense. As a consequence, such therapy may reduce gut inflammation and restore epithelial integrity. $(B)$ In diabetic foot ulcer, the cutaneous wound-healing process is significantly impaired, and the wounded skin is often associated with bacterial infections. IL-22-Fc is thought to increase re-epithelialization through directly stimulating kerantinocytes or indirectly promoting epidermal growth factor (EGF) and keratinocyte growth factor (KGF) production, thereby augmenting antimicrobial peptide production, angiogenesis, chemokine secretion to recruit immune cells, and tissue remodeling, with accelerated wound repair. IEL, Intraepithelial lymphocytes; IL, interleukin; TNF, tumor necrosis factor; DCs, dendritic cells; MMPs, matrix metalloproteinases. 


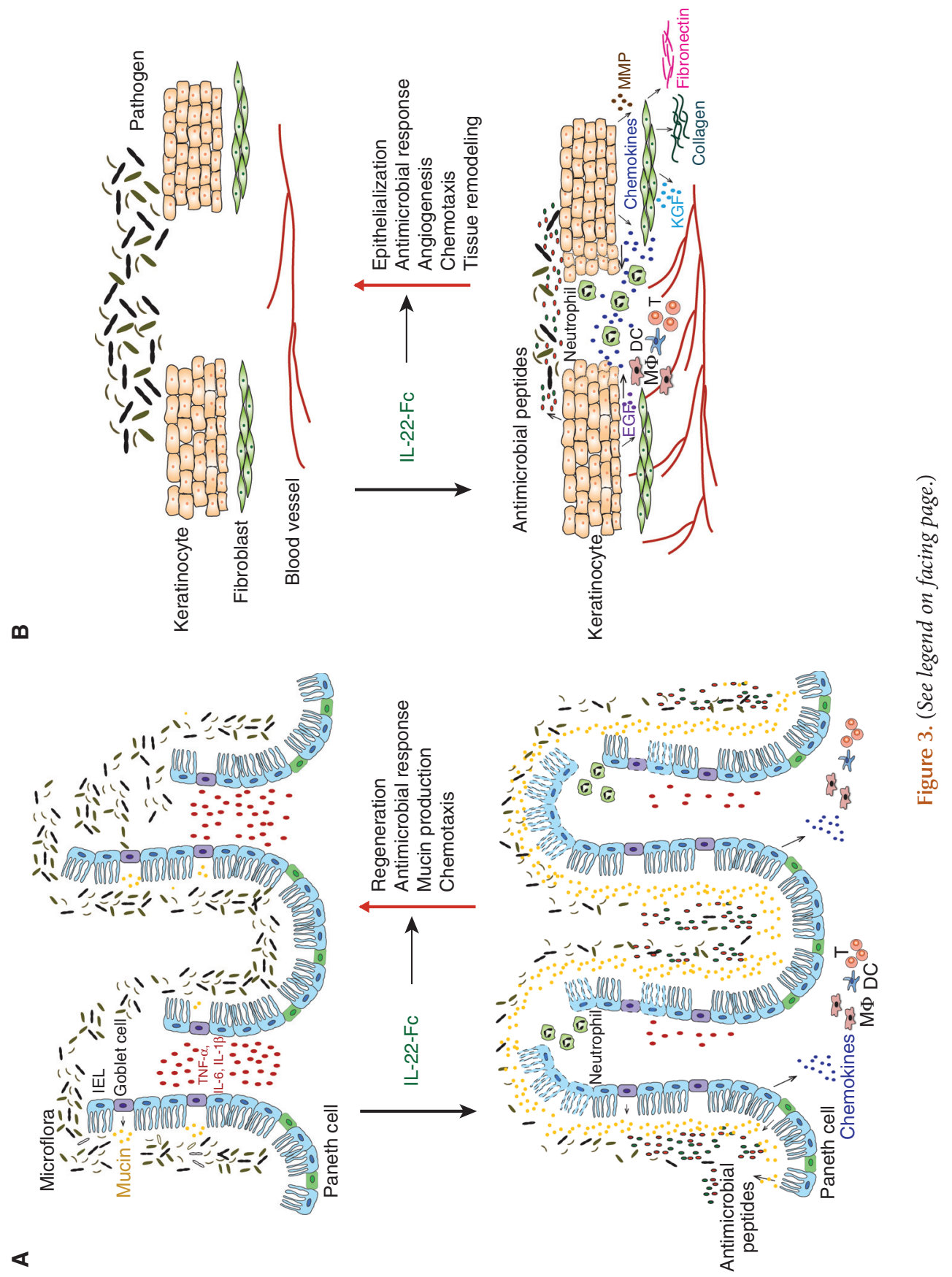


X. Wang et al.

production might result from an increased expression of TGF- $\beta$, as TGF- $\beta$ represses IL-22 production from $\mathrm{T}$ cells (Zheng et al. 2008; Rutz et al. 2011). Furthermore, expression of IL-22BP, acting as a natural IL-22 antagonist, has been detected in mucosal samples from IBD patients (Pelczar et al. 2016). Blockade of the TNF- $\alpha$ pathway can reduce IL-22BP production, suggesting that the enhanced IL-22 activity might be partially attributed to the efficacy of anti-TNF- $\alpha$ therapies in IBD. The beneficial effects of IL-22 in IBD were further supported by a case study of a UC patient (Broadhurst et al. 2010). The reported patient infected himself with the nematode Trichuris trichiura to treat his symptoms. The disease went into remission accompanied by an accumulation of IL-22-producing $\mathrm{CD}^{+} \mathrm{T}$ cells in the intestinal mucosa. Goblet cell hyperplasia and increased mucus production were also observed (Broadhurst et al. 2010).

IL-22 exerts its protective effects at mucosal surfaces (Fig. 3A) by increasing the expression of mucus-associated molecules and restoring goblet cells (Sugimoto et al. 2008). It contributes to intestinal immunity by promoting the formation of secondary lymphoid structures, such as colonic patches, in the gut (Ota et al. 2011). Furthermore, IL-22 induces the production of various antimicrobial peptides and enhances innate intestinal defense functions (Zheng et al. 2008; Zenewicz et al. 2013). Finally, IL-22 fosters the repair of epithelial barriers by promoting epithelial cell proliferation and the expansion of intestinal stem cells (Pickert et al. 2009; Huber et al. 2012; Lindemans et al. 2015).

Studies in mice have shown a beneficial role for IL-22 in various colitis models. IL-22-deficient mice (Zenewicz et al. 2008) or mice receiving neutralizing anti-IL-22 antibodies (Sugimoto et al. 2008) show increased disease severity, as evidenced by extensive epithelial destruction and inflammation in the colon, in creased weight loss, and delayed recovery in a DSS-induced acute colitis model. In a T-cell transfer model of colitis, the transfer of IL-22deficient naïve $\mathrm{CD} 4^{+} \mathrm{T}$ cells cause more severe colitis than the transfer of wild-type $\mathrm{CD}^{+} \mathrm{T}$ cells (Zenewicz et al. 2008). In a C. rodentium- dependent colitis model, in which wild-type mice normally recover from the infection, IL22-deficient mice do not (Zheng et al. 2008; Ota et al. 2011). Conversely, an increase in IL22 levels either by administration of recombinant cytokine or hydrodynamic tail vein injection of IL-22-encoding plasmids ameliorates disease in various colitis models (Sugimoto et al. 2008; Zenewicz et al. 2008; Ota et al. 2011).

However, several potential caveats must be considered carefully before moving IL-22 forward as a treatment for IBD. Despite its tissueprotective role, IL-22 is a proinflammatory cytokine that can enhance inflammation, especially in synergy with other cytokines (Rutz et al. 2014). Indeed, a pathogenic role of IL-22 has been described in certain colitis models (Kamanaka et al. 2011). Furthermore, IL-22 targets many other organs such as skin, liver, and lung, and the downstream effects on these organs following systemic administration of IL22 need to be considered (Park et al. 2011). Lastly, IL-22 activates STAT3 and promotes proliferation of many epithelial cell types. STAT3 is well known for its oncogenic activity in many epithelial tumors (Yu et al. 2014). Many cell types expressing IL-22R have been associated with neoplastic proliferation and IL-22-expressing cells have been detected in carcinomas of the colon (Jiang et al. 2013), stomach (Zhuang et al. 2012), liver (Jiang et al. 2013), and lung (Kobold et al. 2013). Increased colon tumorigenesis is observed when IL-22 is elevated in mice with colitis undergoing carcinogen treatment (Kirchberger et al. 2013) or in mice bearing a genetic alteration $\left(\mathrm{Apc}^{\mathrm{Min} /+}\right)$ that causes colorectal cancer (Huber et al. 2012). However, studies in transgenic mouse models suggest that long-term ectopic expression of IL-22 itself is insufficient to cause cancer (Park et al. 2011; Wang et al. 2011). Given that chronic inflammation is a risk factor for colon cancer, the beneficial effect of IL-22 in reducing tissue damage and inflammation might actually decrease the risk of early oncogenesis (Huber et al. 2012).

In conclusion, strong genetic and mechanistic data support a novel strategy for treating IBD by enhancing barrier function and intestinal in- 
nate defense, which is an approach that is differentiated from current therapies that mainly rely on systemic anti-inflammatory agents, such as TNF- $\alpha$ blockers (Ouyang 2010). To modulate the activity of IL-22 and to prolong its half-life, we generated murine IL-22-Fc fusion proteins (Ota et al. 2011; Wang et al. 2014). These molecules have a longer half-life in vivo, are able to induce downstream effector functions similar to IL-22, and protect intestinal integrity in various models.

Tissue Protective and Regenerative Effects of IL-22 in Pancreatitis and Hepatitis

In addition to skin and intestinal epithelial cells, the IL-22 receptor is also expressed in liver, pancreas, lung, kidney, and many other cell types of epithelial origin (Ouyang et al. 2011; Rutz et al. 2014). Recent advances in IL-22 biology revealed profound effects of IL-22 in tissue protection and regeneration in many organs including liver, pancreas, thymus, and skin (Radaeva et al. 2004; Zenewicz et al. 2008; Dudakov et al. 2012; Feng et al. 2012b; Kolumam et al. 2017). Acinar cells in the pancreas have the highest expression level of IL-22 receptor in the body (Xie et al. 2000; Aggarwal et al. 2001; Huan et al. 2016). Pancreatitis, an inflammatory condition, can occur in acute or chronic forms (Braganza et al. 2011; Banks et al. 2013). Excessive alcohol consumption, gallstones, and autoimmune diseases are some of its leading causes. The current treatment for pancreatitis is supportive and no curative therapy is available. A protective role of IL-22 in murine pancreatitis models has been described, suggesting a therapeutic potential for IL-22-based therapies (Feng et al. 2012b; Huan et al. 2016). Elevated IL-22 levels protect mice from cerulein-induced acute pancreatitis, as evidenced by a reduction in serum digestive enzymes, apoptosis, and infiltration with inflammatory cells (Feng et al. 2012b). Increased IL-22 levels inhibit autophagosome formation through STAT3-dependent regulation of Bcl-2 and Bcl-XL (Feng et al. 2012b; Huan et al. 2016). Furthermore, IL-22 up-regulates the expression of Reg3 (Hill et al. 2013; Huan et al. 2016), which protects acinar cells against injury and inflammation. IL-22 has not yet been tested clinically for the treatment of pancreatitis.

Hepatitis is commonly associated with viral infections or excessive alcohol consumption. Patients with chronic hepatitis B virus (HBV) or hepatitis $\mathrm{C}$ virus (HCV) infection show increased numbers of IL-22-producing cells and corresponding elevated levels of IL-22 (Dambacher et al. 2008; Park et al. 2011). Administration of recombinant IL-22 protein (Radaeva et al. 2004), delivery of an IL-22-expression construct via hydrodynamic tail vein injection (Pan et al. 2004), or transgenic expression of IL-22 under a liver-specific albumin promoter (Park et al. 2011) protect mice from liver damage in hepatitis models, such as concanavalin A-induced T-cell-mediated hepatitis. In contrast, inhibition of IL-22 by neutralizing antibodies (Radaeva et al. 2004) or genetic ablation of IL22 (Zenewicz et al. 2007) worsens liver damage in these models. In acute and chronic mouse models of alcohol-induced liver damage, treatment with IL-22 ameliorates alcoholic fatty liver, liver injury, and hepatic oxidative stress (Ki et al. 2010; Xing et al. 2011). The protective effects of IL-22 in the liver are thought to be mediated through STAT3 and the induction of antiapoptotic, mitogenic, and antioxidant pathways in hepatocytes and liver stem cells (Pan et al. 2004; Radaeva et al. 2004; Feng et al. 2012a). Based on these preclinical data, an IL-22-IgG2 fusion protein is currently being tested in the clinic for the treatment of alcoholic hepatitis (Table 2).

\section{A Protective Role for IL-22 in Graft-Versus- Host Disease}

Allogeneic hematopoietic stem-cell transplantation holds great promise for the treatment of malignant and nonmalignant hematologic diseases. The major obstacle that hinders successful transplantation is graft-versus-host disease (GVHD) (Ferrara et al. 2009), which is associated with severe morbidity and mortality (Wingard et al. 2011). Both innate and adaptive immune cells are thought to be involved in the pathophysiology of GVHD (Ferrara et al. 2009; Konya and Mjösberg 2015). Interestingly, an 
X. Wang et al.

increased number of donor-derived ILCs in the blood correlates with reduced severity of GVHD in patients (Munneke et al. 2014). A recent study in mice reported a protective role of IL-22 in GVHD during transplantation of intestinal stem cells (Hanash et al. 2012). Intestinal stem cells and downstream progenitor cells express the IL-22 receptor (Hanash et al. 2012), which can promote epithelial regeneration through STAT3-dependent mechanisms in response to IL-22 secreted from various sources, including ILC3s (Hanash et al. 2012). Furthermore, administration of IL-22 promotes the recovery of intestinal stem cells and intestinal regeneration, and reduces mortality from GVHD in transplanted animals (Hanash et al. 2012). IL-22 deficiency in the recipient, on the other hand, increases tissue damage and mortality as the result of acute GVHD (Hanash et al. 2012). A clinic trial is currently ongoing to evaluate the therapeutic potential of IL-22 in GVHD (Table 2).

Potential Therapeutic Applications for IL-20 Subfamily Cytokines to Enhance Wound Healing in Diabetic Foot Ulcer

A regulated topical wound-healing response restores tissue homeostasis and immune defense mechanisms in the skin (Singer and Clark 1999; $\mathrm{Li}$ et al. 2007). The healing process can be divided into several overlapping phases: hemostasis, inflammation, angiogenesis, re-epithelialization, and remodeling or maturation. These phases involve many types of tissue cells, immune cells, and soluble factors, such as cytokines and growth factors. DFU is a chronic wound with impeded healing. As one of the major complications of type II diabetes, diabetic ulcers lead to a significant number of amputations, and increase the morbidity and mortality of diabetes patients (Jeffcoate and Harding 2003; Boulton et al. 2005). The impaired wound healing is in part because of deficiencies in leukocyte recruitment, macrophage function, angiogenesis, extracellular matrix deposition, epidermal barrier function, and fibroblast activities under diabetic conditions (Falanga 2005; Brem and Tomic-Canic 2007). Frequently, wound site infections in DFU patients are difficult to control and further hinder the wound-healing process.

Several IL-20 subfamily cytokines participate in the different stages of the wound-healing response (Fig. 3B) by regulating re-epithelialization, immune cell infiltration, production of growth factors, and tissue remodeling (Rutz et al. 2014). Mice ectopically expressing IL-20 subfamily cytokines develop skin pathogenesis that resembles human psoriasis, which can be viewed as an excessive wound-healing response (Blumberg et al. 2001; Wolk et al. 2009a; He and Liang 2010). All IL-20 subfamily cytokines are induced during normal wound healing in mouse models, and elevated IL-24 levels have been identified in biopsies of human wounded skin (Bosanquet et al. 2012; Kolumam et al. 2017). The receptors for IL-20 subfamily cytokines are expressed primarily on keratinocytes in the skin (Sa et al. 2007). Studies conducted in vitro and in vivo have shown several downstream pathways induced by IL-20 subfamily cytokines to contribute to different stages of wound healing (Wolk and Sabat 2006; Sa et al. 2007; Rutz et al. 2014). All IL-20 subfamily cytokines promote re-epithelialization by stimulating the proliferation of epidermal keratinocytes and by inducing EGF and KGF production from keratinocytes (Sa et al. 2007). They also trigger chemokine production from keratinoytes and thereby enhance inflammatory infiltration of leukocytes, especially macrophages. In addition, all IL-20 subfamily cytokines induce vascular endothelial growth factor (VEGF), an important growth factor that facilitates angiogenesis and neovascularization (Sa et al. 2007; Kolumam et al. 2017). Importantly, they induce the expression of various antimicrobial peptides from keratinocytes to dampen infections that are commonly associated with wounded skin. Finally, IL-20 subfamily cytokines induce the production of many proteases and extracellular matrix proteins from keratinocytes and fibroblasts to mediate scar formation and tissue remodeling. IL-22 is the most potent, followed by IL-24 and IL-20, with IL-19 being the least effective family member with regard to its wound-healing activity. Yet, various IL-20 sub- 
family members appear to have redundant functions (McGee et al. 2013; Kolumam et al. 2017).

In preclinical models, topical treatment of wounded skin with recombinant IL-19, IL-20, or Fc-fusion proteins of IL-20, IL-22, and IL-24 accelerates the cutaneous healing process in mice (Sun et al. 2013; Kolumam et al. 2017). The therapeutic potential of IL-22, IL-20, and IL-24 has also been studied in diabetic woundhealing models. In streptozotocin-induced type I diabetic mice, topical treatment with recombinant IL-22 accelerates wound closure compared with control-treated diabetic wounds (Avitabile et al. 2015). Re-epithelialization of wounds treated with IL-22 is significantly improved. Another study examined the therapeutic effect of IL-22R-binding cytokines in diabetic wound repair in db/db mice (Kolumam et al. 2017), a commonly used mouse model for type II diabetes, which shows much slower wound closure compared with other diabetes models (Michaels et al. 2007). Both systemic and topical application of Fc fusion versions of IL-20, IL-22, and IL-24 significantly accelerates wound closure in $\mathrm{db} / \mathrm{db}$ mice, independent of their metabolic functions (Wang et al. 2014; Kolumam et al. 2017). Gene-expression analysis revealed that IL-22-Fc treatment specifically promotes the activity of critical pathways for re-epithelialization, tissue remodeling, host defense, and fatty acid/lipid metabolism compared with PDGF or VEGF treatment. Many genes that are up-regulated by IL-22-Fc have been reported to participate in cutaneous wound healing, such as Cxcr2, GrhI3, and Klk8 (Kolumam et al. 2017).

\section{THE INTERFERON $\lambda$ SUBFAMILY IL-28A, IL-28B, IL-29}

The genes encoding IL-28A (IFN- $\lambda 2$ ), IL-28B (IFN- $\lambda 3$ ), and IL-29 (IFN- $\lambda 1$ ) were identified based on their homology with genes of the IFN/IL-10 superfamily of cytokines (Kotenko et al. 2003; Sheppard et al. 2003; Fox et al. 2009). Structurally, these three cytokines are more closely related to IL-10 family cytokines, in particular to IL-22 (Gad et al. 2009). They signal through the IL-10R2 chain, also used by
Targeting IL-10 Family Cytokines to Treat Diseases

other IL-10 family cytokines, but they use a unique IL-28R as their receptor $\alpha$ chain (Kotenko et al. 2003; Sheppard et al. 2003). Despite differences in receptor usage, downstream signaling shows substantial overlap with IFN- $\alpha / \beta$ (Ouyang et al. 2011; Durbin et al. 2013). Accordingly, IFN- $\lambda$ and type I IFNs trigger similar biological effects and antiviral responses (Onoguchi et al. 2007; Kotenko et al. 2003). However, substantial differences exist with regard to the magnitude and kinetics of IFN-sensitive gene (ISG) induction. Whereas IFN- $\alpha$ strongly induces ISGs with an early peak followed by rapid down-regulation, IFN- $\lambda$ triggers a weak but sustained ISG response (Kotenko et al. 2003; Meager et al. 2005; Marcello et al. 2006). More importantly, in contrast to a broad range of cells that respond to type I IFNs, only a few cell types, in particular epithelial cells (Fig. 1), respond to type III IFNs (Sommereyns et al. 2008; Witte et al. 2009). This has led to the idea that IFN- $\lambda$ and IL-20 subfamily members serve parallel functions in protecting epithelial tissue against viral and bacterial infections, respectively (Gad et al. 2009).

\section{IFN- $\lambda$ for the Treatment of Viral Infections}

Generally speaking, IFN- $\lambda$ s induce relatively weak antiviral responses. However, GWAS identified a role for polymorphisms near the IFNL3 gene in the control of HCV infection, as well as other viruses with epithelial cell tropism. IFN- $\lambda \mathrm{s}$ are in fact the dominant IFN subclass produced in the liver of humans, chimpanzees, and in primary human hepatocyte cultures infected with HCV (Park et al. 2012; Thomas et al. 2012). A genetic polymorphism linked to the gene for IL$28 \mathrm{~B}$ has been associated with clinical response to IFN- $\alpha$ and ribavirin therapy in patients with chronic HCV infection (Ge et al. 2009; Suppiah et al. 2009; Tanaka et al. 2009; Thomas et al. 2009), suggesting cooperation between the IFN- $\lambda$ and type I IFN responses during host defense. A critical function for IFN- $\lambda$ has been reported for a variety of preclinical models of pulmonary infections in mice, including influenza $A$, influenza $B$, severe acute respiratory syndrome (SARS), coronavirus, and H1N1 influen- 
X. Wang et al.

za virus (Mordstein et al. 2008, 2010). Furthermore, IFN- $\lambda$ s have the ability to inhibit the replication of multiple other viruses, including human immunodeficiency virus (HIV) (Hou et al. 2009), herpes simplex virus type 2 (HSV2) (Ank et al. 2006), cytomegalovirus (CMV) (Brand et al. 2005), and encephalomyocarditis virus (EMCV) (Hou et al. 2009).

IFN- $\lambda$ is an attractive therapeutic target for the treatment of viral infections. The more restricted expression of IFN- $\lambda$ receptors predominantly on epithelial cells suggests that IFN- $\lambda$, although sharing the same therapeutic advantages, might avoid many of the systemic side effects of IFN- $\alpha / \beta$. Furthermore, there is genetic evidence that certain IFNL3/IFNL4 polymorphisms are linked to the clearance of HCV infection and potentially other types of infections (Miller et al. 2009). Type I and II IFNs are currently approved for the treatment of $\mathrm{HCV}$ and HBV (Gibbert et al. 2013; Lin and Young 2014).

A PEGylated IFN- $\lambda 1$ has been evaluated in clinical trials for the treatment of HCV (Table 3). A phase II trial showed that IFN- $\lambda 1$ was as effective as PEGylated IFN- $\alpha$ with significantly fewer extrahepatic adverse events, such as neutropenia, thrombocytopenia, flu-like symptoms, autoimmune thyroid disease, and pulmonary arterial hypertension (Muir et al. 2014; Fredlund et al. 2015). Several phase III clinical trials are currently ongoing (Friborg et al. 2013).

However, the availability of highly efficacious direct-acting antiviral agents (DAAs) makes it highly unlikely for IFN- $\lambda$ to play a major role for HCV therapy in the future. Although efficacy will have to be shown in the clinic, IFN- $\lambda$ could potentially hold promise for the treatment of select infections with epithelial tropism, such as intestinal infection caused by rotaviruses or noroviruses, and respiratory infections caused by viruses, such as influenza virus or coronaviruses.

\section{Role for IFN- $\lambda$ in Cancer}

IFN- $\lambda$ is induced in the tumor microenvironment, either through viral infections or other mechanisms, and shows antitumor activity (Steen and Gamero 2010; Burkart et al. 2013; Cannella et al. 2014). Depending on receptor expression, IFN- $\lambda$ induces apoptosis in various murine and human cancer cells. Responsive tumors include neuroendocrine tumors, colorectal/intestinal carcinoma, hepatocellular carcinoma, esophageal carcinoma, lung adenocarcinomas, Burkitt lymphoma, and melanoma (Sato et al. 2006; Zitzmann et al. 2006; Guenterberg et al. 2010; Li et al. 2010; Steen and Gamero 2010). In a mouse model of breast cancer, for example, IFN- $\lambda$ expression on mammary epithelial cells inversely correlates with tumor growth (Burkart et al. 2013). IFN- $\lambda$ s induce apoptosis in colorectal cancer cells more potently than IFN$\alpha / \beta$ or IFN- $\gamma$ (Li et al. 2008), and show comparable potency in a mouse hepatoma model (Abushahba et al. 2010). Interestingly, the combination of IFN- $\lambda$ and IFN- $\alpha$ showed more substantial antitumor activity than either IFN alone (Lasfar et al. 2016). Like other IFNs, IFN- $\lambda$ s possess immune stimulatory activities and enhance antitumor immunity through various mechanisms (Numasaki et al. 2007; Li et al. 2010; Steen

Table 3. Clinical trials targeting interleukin (IL)-29

\begin{tabular}{llll}
\hline Intervention & Indication & \multicolumn{1}{c}{ Clinical stage } & Sponsor \\
\hline PEG-rIL-29 & Hepatitis C & Phase I NCT00565539 & ZymoGenetics \\
& & Phase II NCT01001754 & \\
PEG-rIL-29 & Phase III NCT01718158 & Bristol-Myers Squibb \\
& & Phase III NCT01598090 & \\
& Phase III NCT01754974 & \\
& Phase III NCT01866930 & \\
& & Phase III NCT01616524 & Eiger BioPharmaceuticals \\
\hline
\end{tabular}

Data source: clinicaltrials.gov. 
Targeting IL-10 Family Cytokines to Treat Diseases

and Gamero 2010). Accordingly, antitumor activity has also been observed in models in which the tumor cells themselves are not responsive to IFN- $\lambda$ (Sato et al. 2006). To date, IFN- $\lambda$ has not been studied clinically as a cancer therapy.

\section{CONCLUDING REMARKS}

Over the past three decades, a number of cytokines have been targeted successfully for the treatment of a wide spectrum of human disorders (O'Shea et al. 2014). In fact, since the approval of recombinant IFN- $\alpha 2 b$ for the treatment of chronic HBV infection, therapies targeting members of most cytokine families, including IL-1, IL-2 $\gamma$ c, IL-6, IL-12, IL-17, and TNF- $\alpha$, have been developed for clinical use in autoimmune disorders, infectious diseases, and cancer. However, despite their known essential immune regulatory functions in host defense and tissue protection, the IL-10 family of cytokines is currently an exception with no approved therapies for any indication. As we have discussed, part of the reason is that we are still in the early stages of understanding the pleiotropic functions of many cytokines in this family. The degree of functional redundancy within the IL20 subfamily further complicates targeting these cytokines. However, given the recent advances in our understanding of the diverse biology of IL-10 family cytokines, combined with technical progress in protein engineering, and innovative targeting and delivery strategies, we are increasingly able to modulate these cytokine pathways in a cell-type- and disease-specific manner. Novel therapies targeting IL-10 family cytokines that will improve the lives of patients may therefore be within reach.

\section{REFERENCES}

Abushahba W, Balan M, Castaneda I, Yuan Y, Reuhl K, Raveche E, la Torre de A, Lasfar A, Kotenko SV. 2010. Antitumor activity of type I and type III interferons in BNL hepatoma model. Cancer Immunol Immunother 59: 1059-1071.

Adris S, Klein S, Jasnis M, Chuluyan E, Ledda M, Bravo A, Carbone C, Chernajovsky Y, Podhajcer O. 1999. IL-10 expression by CT26 colon carcinoma cells inhibits their malignant phenotype and induces a T-cell-mediated tu- mor rejection in the context of a systemic Th2 response. Gene Ther 6: 1705-1712.

Aggarwal S, Xie MH, Maruoka M, Foster J, Gurney AL. 2001. Acinar cells of the pancreas are a target of interleukin-22. J Interferon Cytokine Res 21: 1047-1053.

Alanärä T, Karstila K, Moilanen T, Silvennoinen O, Isomäki P. 2010. Expression of IL-10 family cytokines in rheumatoid arthritis: Elevated levels of IL-19 in the joints. Scand J Rheumatol 39: 118-126.

Andoh A, Zhang Z, Inatomi O, Fujino S, Deguchi Y, Araki Y, Tsujikawa T, Kitoh K, Kim-Mitsuyama S, Takayanagi A, et al. 2005. Interleukin-22, a member of the IL-10 subfamily, induces inflammatory responses in colonic subepithelial myofibroblasts. Gastroenterology 129: 969-984.

Ank N, West H, Bartholdy C, Eriksson K, Thomsen AR, Paludan SR. 2006. Lambda interferon (IFN- $\lambda$ ), a type III IFN, is induced by viruses and IFNs and displays potent antiviral activity against select virus infections in vivo. J Virol 80: 4501-4509.

Asadullah K, Sterry W, Stephanek K, Jasulaitis D, Leupold M, Audring H, Volk H-D, Döcke WD. 1998. IL-10 is a key cytokine in psoriasis. Proof of principle by IL-10 therapy: A new therapeutic approach. J Clin Invest 101: 783-794.

Asadullah K, Sterry W, Volk H-D. 2003. Interleukin-10 therapy-Review of a new approach. Pharmacol Rev 55: 241269.

Avitabile S, Odorisio T, Madonna S, Eyerich S, Guerra L, Eyerich K, Zambruno G, Cavani A, Cianfarani F. 2015. Interleukin-22 promotes wound repair in diabetes by improving keratinocyte pro-healing functions. J Invest Dermatol 135: 2862-2870.

Banks PA, Bollen TL, Dervenis C, Gooszen HG, Johnson CD, Sarr MG, Tsiotos GG, Vege SS; Acute Pancreatitis Classification Working Group. 2013. Classification of acute pancreatitis-2012: Revision of the Atlanta classification and definitions by international consensus. Gut 62: 102-111.

Benbouziane B, Ribelles P, Aubry C, Martin R, Kharrat P, Riazi A, Langella P, Bermúdez-Humarán LG. 2013. Development of a stress-inducible controlled expression (SICE) system in Lactococcus lactis for the production and delivery of therapeutic molecules at mucosal surfaces. J Biotechnol 168: 120-129.

Blumberg H, Conklin D, Xu WF, Grossmann A, Brender T, Carollo S, Eagan M, Foster D, Haldeman BA, Hammond A, et al. 2001. Interleukin 20: Discovery, receptor identification, and role in epidermal function. Cell 104: 9-19.

Boniface K, Bernard FX, Garcia M, Gurney AL, Lecron JC, Morel F. 2005. IL-22 inhibits epidermal differentiation and induces proinflammatory gene expression and migration of human keratinocytes. J Immunol 174: 36953702.

Boniface K, Guignouard E, Pedretti N, Garcia M, Delwail A, Bernard FX, Nau F, Guillet G, Dagregorio G, Yssel H, et al. 2007. A role for T cell-derived interleukin 22 in psoriatic skin inflammation. Clin Exp Immunol 150: 407-415.

Borghaei H, Paz-Ares L, Horn L, Spigel DR, Steins M, Ready NE, Chow LQ, Vokes EE, Felip E, Holgado E, et al. 2015. Nivolumab versus docetaxel in advanced nonsquamous non-small-cell lung cancer. N Engl J Med 373: 1627-1639.

Bosanquet DC, Harding KG, Ruge F, Sanders AJ, Jiang WG. 2012. Expression of IL-24 and IL-24 receptors in human 
X. Wang et al.

wound tissues and the biological implications of IL-24 on keratinocytes. Wound Repair Regen 20: 896-903.

Boulton AJM, Vileikyte L, Ragnarson-Tennvall G, Apelqvist J. 2005. The global burden of diabetic foot disease. Lancet 366: 1719-1724

Braganza JM, Lee SH, McCloy RF, McMahon MJ. 2011. Chronic pancreatitis. Lancet 377: 1184-1197.

Brand S, Beigel F, Olszak T, Zitzmann K, Eichhorst ST, Otte JM, Diebold J, Diepolder H, Adler B, Auernhammer CJ, et al. 2005. IL-28A and IL-29 mediate antiproliferative and antiviral signals in intestinal epithelial cells and murine CMV infection increases colonic IL-28A expression. Am J Physiol Gastrointest Liver Physiol 289: G960-G968.

Brem H, Tomic-Canic M. 2007. Cellular and molecular basis of wound healing in diabetes. J Clin Invest 117: 12191222.

Broadhurst MJ, Leung JM, Kashyap V, McCune JM, Mahadevan U, McKerrow JH, Loke P. 2010. IL-22 ${ }^{+} \mathrm{CD}^{+} \mathrm{T}$ cells are associated with therapeutic Trichuris trichiura infection in an ulcerative colitis patient. Sci Transl Med 2: 60 ra88.

Burkart C, Arimoto KI, Tang T, Cong X, Xiao N, Liu YC, Kotenko SV, Ellies LG, Zhang DE. 2013. Usp18 deficient mammary epithelial cells create an antitumour environment driven by hypersensitivity to IFN- $\lambda$ and elevated secretion of Cxcl10. EMBO Mol Med 5: 1035-1050.

Buruiana FE, Solà I, Alonso-Coello P. 2010. Recombinant human interleukin 10 for induction of remission in Crohn's disease. Cochrane Database Syst Rev 119: CD005109.

Cannella B, Gao YL, Brosnan C, Raine CS. 1996. IL-10 fails to abrogate experimental autoimmune encephalomyelitis. J Neurosci Res 45: 735-746.

Cannella F, Scagnolari C, Selvaggi C, Stentella P, Recine N, Antonelli G, Pierangeli A. 2014. Interferon $\lambda 1$ expression in cervical cells differs between low-risk and high-risk human papillomavirus-positive women. Med Microbiol Immunol 203: 177-184.

Cassatella MA, Meda L, Bonora S, Ceska M, Constantin G. 1993. Interleukin 10 (IL-10) inhibits the release of proinflammatory cytokines from human polymorphonuclear leukocytes. Evidence for an autocrine role of tumor necrosis factor and IL-1 $\beta$ in mediating the production of IL8 triggered by lipopolysaccharide. J Exp Med 178: 22072211.

Caudell EG, Mumm JB, Poindexter N, Ekmekcioglu S, Mhashilkar AM, Yang XH, Retter MW, Hill P, Chada S, Grimm EA. 2002. The protein product of the tumor suppressor gene, melanoma differentiation-associated gene 7 , exhibits immunostimulatory activity and is designated IL-24. J Immunol 168: 6041-6046.

Chan JR, Blumenschein W, Murphy E, Diveu C, Wiekowski M, Abbondanzo S, Lucian L, Geissler R, Brodie S, Kimball $\mathrm{AB}$, et al. 2006. IL-23 stimulates epidermal hyperplasia via TNF and IL-20R2-dependent mechanisms with implications for psoriasis pathogenesis. J Exp Med 203: 25772587.

Chen DS, Mellman I. 2017. Elements of cancer immunity and the cancer-immune set point. Nature 541: 321-330.

Chernoff AE, Granowitz EV, Shapiro L, Vannier E, Lonnemann G, Angel JB, Kennedy JS, Rabson AR, Wolff SM, Dinarello CA. 1995. A randomized, controlled trial of IL-
10 in humans. Inhibition of inflammatory cytokine production and immune responses. J Immunol 154: 54925499.

Colombel JF, Rutgeerts P, Malchow H, Jacyna M, Nielsen OH, Rask-Madsen J, Van Deventer S, Ferguson A, Desreumaux P, Forbes A, et al. 2001. Interleukin 10 (Tenovil) in the prevention of postoperative recurrence of Crohn's disease. Gut 49: 42-46.

Corvaisier M, Delneste Y, Jeanvoine H, Preisser L, Blanchard S, Garo E, Hoppe E, Barré B, Audran M, Bouvard B, et al. 2012. IL-26 is overexpressed in rheumatoid arthritis and induces proinflammatory cytokine production and Th17 cell generation. PloS Biol 10: e1001395.

Creery WD, Diaz-Mitoma F, Filion L, Kumar A. 1996. Differential modulation of B7-1 and B7-2 isoform expression on human monocytes by cytokines which influence the development of T helper cell phenotype. Eur J Immunol 26: 1273-1277.

Cunningham CC, Chada S, Merritt JA, Tong A, Senzer N, Zhang Y, Mhashilkar A, Parker K, Vukelja S, Richards D, et al. 2005. Clinical and local biological effects of an intratumoral injection of $m d a-7$ (IL24; INGN 241) in patients with advanced carcinoma: A phase I study. Mol Ther 11: 149-159.

Dambacher J, Beigel F, Zitzmann K, Heeg MHJ, Göke B, Diepolder HM, Auernhammer CJ, Brand S. 2008. The role of interleukin-22 in hepatitis $\mathrm{C}$ virus infection. Cytokine 41: 209-216.

D'Andrea A, Aste-Amezaga M, Valiante NM, Ma X, Kubin M, Trinchieri G. 1993. Interleukin 10 (IL-10) inhibits human lymphocyte interferon $\lambda$-production by suppressing natural killer cell stimulatory factor/IL-12 synthesis in accessory cells. J Exp Med 178: 1041-1048.

da Rocha LF, Duarte ALBP, Dantas AT, Mariz HA, Pitta IDR, Galdino SL, Pitta MGDR. 2012. Increased serum interleukin 22 in patients with rheumatoid arthritis and correlation with disease activity. J Rheumatol 39: 13201325.

Dejaco C, Reinisch W, Lichtenberger C, Waldhoer T, Kuhn I, Tilg H, Gasche C. 2000. In vivo effects of recombinant human interleukin-10 on lymphocyte phenotypes and leukocyte activation markers in inflammatory bowel disease. J Investig Med 48: 449-456.

del Carmen S, de Moreno de LeBlanc A, Perdigon G, Bastos Pereira V, Miyoshi A, Azevedo V, LeBlanc JG. 2011. Evaluation of the anti-inflammatory effect of milk fermented by a strain of IL-10-producing Lactococcus lactis using a murine model of Crohn's disease. J Mol Microbiol Biotechnol 21: 138-146.

del Carmen S, Martín Rosique R, Saraiva T, Zurita-Turk M, Miyoshi A, Azevedo V, de Moreno de LeBlanc A, Langella P, Bermúdez-Humarán LG, LeBlanc JG. 2014. Protective effects of lactococci strains delivering either IL-10 protein or CDNA in a TNBS-induced chronic colitis model. J Clin Gastroenterol 48 (Suppl 1): S12-S17.

de Waal-Malefyt R, Abrams J, Bennett B, Figdor CG, de Vries JE. 1991a. Interleukin 10(IL-10) inhibits cytokine synthesis by human monocytes: An autoregulatory role of IL-10 produced by monocytes. J Exp Med 174: 12091220.

de Waal-Malefyt R, Haanen J, Spits H, Roncarolo MG, Velde Te A, Figdor C, Johnson K, Kastelein R, Yssel H, de Vries 
Targeting IL-10 Family Cytokines to Treat Diseases

JE. 1991b. Interleukin 10 (IL-10) and viral IL-10 strongly reduce antigen-specific human $\mathrm{T}$ cell proliferation by diminishing the antigen-presenting capacity of monocytes via downregulation of class II major histocompatibility complex expression. J Exp Med 174: 915-924.

Doll F, Schwager K, Hemmerle T, Neri D. 2013. Murine analogues of etanercept and of F8-IL10 inhibit the progression of collagen-induced arthritis in the mouse. Arthritis Res Ther 15: R138.

Drouault S, Corthier G, Ehrlich SD, Renault P. 1999. Survival, physiology, and lysis of Lactococcus lactis in the digestive tract. Appl Environ Microbiol 65: 4881-4886.

Dudakov JA, Hanash AM, Jenq RR, Young LF, Ghosh A, Singer NV, West ML, Smith OM, Holland AM, Tsai JJ, et al. 2012. Interleukin-22 drives endogenous thymic regeneration in mice. Science 336: 91-95.

Durbin RK, Kotenko SV, Durbin JE. 2013. Interferon induction and function at the mucosal surface. Immunol Rev 255: 25-39.

Eidenschenk C, Rutz S, Liesenfeld O, Ouyang W. 2014. Role of IL-22 in microbial host defense. Curr Top Microbiol Immunol 380: 213-236.

Emdad L, Lebedeva IV, Su ZZ, Gupta P, Sauane M, Dash R, Grant S, Dent P, Curiel DT, Sarkar D, et al. 2009. Historical perspective and recent insights into our understanding of the molecular and biochemical basis of the antitumor properties of mda-7/IL-24. Cancer Biol Ther 8: 391400.

Emmerich J, Mumm JB, Chan IH, LaFace D, Truong H, McClanahan T, Gorman DM, Oft M. 2012. IL-10 directly activates and expands tumor-resident $\mathrm{CD} 8^{+} \mathrm{T}$ cells without de novo infiltration from secondary lymphoid organs. Cancer Res 72: 3570-3581.

Engelhardt KR, Shah N, Faizura-Yeop I, Kocacik Uygun DF, Frede N, Muise AM, Shteyer E, Filiz S, Chee R, Elawad M, et al. 2013. Clinical outcome in IL-10- and IL-10 receptordeficient patients with or without hematopoietic stem cell transplantation. J Allergy Clin Immunol 131: 825-830.

Falanga V. 2005. Wound healing and its impairment in the diabetic foot. Lancet 366: 1736-1743.

Feagan BG, Sandborn WJ, Gasink C, Jacobstein D, Lang Y, Friedman JR, Blank MA, Johanns J, Gao LL, Miao Y, et al. 2016. Ustekinumab as induction and maintenance therapy for Crohn's disease. N Engl J Med 375: 1946-1960.

Fedorak RN, Gangl A, Elson CO, Rutgeerts P, Schreiber S, Wild G, Hanauer SB, Kilian A, Cohard M, LeBeaut A, et al. 2000. Recombinant human interleukin 10 in the treatment of patients with mild to moderately active Crohn's disease. The Interleukin 10 Inflammatory Bowel Disease Cooperative Study Group. Gastroenterology 119: 14731482.

Feng D, Kong X, Weng H, Park O, Wang H, Dooley S, Gershwin ME, Gao B. 2012a. Interleukin-22 promotes proliferation of liver stem/progenitor cells in mice and patients with chronic hepatitis B virus infection. Gastroenterology 143: 188-198.e7.

Feng D, Park O, Radaeva S, Wang H, Yin S, Kong X, Zheng M, Zakhari S, Kolls JK, Gao B. 2012b. Interleukin-22 ameliorates cerulein-induced pancreatitis in mice by inhibiting the autophagic pathway. Int J Biol Sci 8: 249-257.

Ferrara JLM, Levine JE, Reddy P, Holler E. 2009. Graft-versus-host disease. Lancet 373: 1550-1561.
Fiorentino DF, Bond MW, Mosmann TR. 1989. Two types of mouse T helper cell. IV: Th2 clones secrete a factor that inhibits cytokine production by Th1 clones. J Exp Med 170: 2081-2095.

Fiorentino DF, Zlotnik A, Mosmann TR, Howard M, O'Garra A. 1991. IL-10 inhibits cytokine production by activated macrophages. J Immunol 147: 3815-3822.

Fox BA, Sheppard PO, O'Hara PJ. 2009. The role of genomic data in the discovery, annotation and evolutionary interpretation of the interferon- $\lambda$ family. PloS ONE 4: e4933.

Franke A, Balschun T, Karlsen TH, Sventoraityte J, Nikolaus S, Mayr G, Domingues FS, Albrecht M, Nothnagel M, Ellinghaus D, et al. 2008. Sequence variants in IL10, ARPC2 and multiple other loci contribute to ulcerative colitis susceptibility. Nat Genet 40: 1319-1323.

Franke A, McGovern DPB, Barrett JC, Wang K, RadfordSmith GL, Ahmad T, Lees CW, Balschun T, Lee J, Roberts $\mathrm{R}$, et al. 2010. Genome-wide meta-analysis increases to 71 the number of confirmed Crohn's disease susceptibility loci. Nat Genet 42: 1118-1125.

Franz M, Doll F, Grün K, Richter P, Köse N, Ziffels B, Schubert H, Figulla HR, Jung C, Gummert J, et al. 2015. Targeted delivery of interleukin-10 to chronic cardiac allograft rejection using a human antibody specific to the extra domain A of fibronectin. Int J Cardiol 195: 311-322.

Fredlund P, Hillson J, Gray T, Shemanski L, Dimitrova D, Srinivasan S. 2015. Peginterferon Lambda-1a is associated with a low incidence of autoimmune thyroid disease in chronic hepatitis C. J Interferon Cytokine Res 35: 841843.

Friborg J, Levine S, Chen C, Sheaffer AK, Chaniewski S, Voss S, Lemm JA, McPhee F. 2013. Combinations of $\lambda$ interferon with direct-acting antiviral agents are highly efficient in suppressing hepatitis $\mathrm{C}$ virus replication. Antimicrob Agents Chemother 57: 1312-1322.

Gad HH, Dellgren C, Hamming OJ, Vends S, Paludan SR, Hartmann R. 2009. Interferon- $\lambda$ is functionally an interferon but structurally related to the interleukin-10 family. J Biol Chem 284: 20869-20875.

Galeazzi M, Bazzichi L, Sebastiani GD, Neri D, Garcia E, Ravenni N, Giovannoni L, Wilton J, Bardelli M, Baldi C, et al. 2014. A phase IB clinical trial with Dekavil (F8IL10), an immunoregulatory "armed antibody" for the treatment of rheumatoid arthritis, used in combination wiIh methotrexate. Isr Med Assoc J 16: 666.

Ge D, Fellay J, Thompson AJ, Simon JS, Shianna KV, Urban TJ, Heinzen EL, Qiu P, Bertelsen AH, Muir AJ, et al. 2009. Genetic variation in $I L 28 B$ predicts hepatitis C treatmentinduced viral clearance. Nature 461: 399-401.

Geremia A, Arancibia-Cárcamo CV, Fleming MPP, Rust N, Singh B, Mortensen NJ, Travis SPL, Powrie F. 2011. IL-23responsive innate lymphoid cells are increased in inflammatory bowel disease. J Exp Med 208: 1127-1133.

Gibbert K, Schlaak JF, Yang D, Dittmer U. 2013. IFN- $\alpha$ subtypes: Distinct biological activities in anti-viral therapy. Br J Pharmacol 168: 1048-1058.

Gittler JK, Shemer A, Suárez-Fariñas M, Fuentes-Duculan J, Gulewicz KJ, Wang CQF, Mitsui H, Cardinale I, de Guzman Strong C, Krueger JG, et al. 2012. Progressive activation of $\mathrm{T}_{\mathrm{H}} 2 / \mathrm{T}_{\mathrm{H}} 22$ cytokines and selective epidermal proteins characterizes acute and chronic atopic dermatitis. J Allergy Clin Immunol 130: 1344-1354. 
X. Wang et al.

Glocker E-O, Kotlarz D, Boztug K, Gertz EM, Schäffer AA, Noyan F, Perro M, Diestelhorst J, Allroth A, Murugan D, et al. 2009. Inflammatory bowel disease and mutations affecting the interleukin-10 receptor. N Engl J Med 361: 2033-2045.

Gottlieb AB, Krueger JG, Sandberg Lundblad M, Göthberg M, Skolnick BE. 2015. First-in-human, phase 1, randomized, dose-escalation trial with recombinant anti-IL-20 monoclonal antibody in patients with psoriasis. PloS ONE 10: e0134703.

Groux H, Bigler M, de Vries JE, Roncarolo MG. 1996. Interleukin-10 induces a long-term antigen-specific anergic state in human CD4 ${ }^{+} \mathrm{T}$ cells. J Exp Med 184: 19-29.

Groux H, Bigler M, de Vries JE, Roncarolo MG. 1998. Inhibitory and stimulatory effects of IL- 10 on human $\mathrm{CD} 8^{+}$ T cells. J Immunol 160: 3188-3193.

Guenterberg KD, Grignol VP, Raig ET, Zimmerer JM, Chan AN, Blaskovits FM, Young GS, Nuovo GJ, Mundy BL, Lesinski GB, et al. 2010. Interleukin-29 binds to melanoma cells inducing Jak-STAT signal transduction and apoptosis. Mol Cancer Ther 9: 510-520.

Guilloteau K, Paris I, Pedretti N, Boniface K, Juchaux F, Huguier V, Guillet G, Bernard F-X, Lecron J-C, Morel F. 2010. Skin inflammation induced by the synergistic action of IL-17A, IL-22, oncostatin M, IL-1 $\alpha$, and TNF$\alpha$ recapitulates some features of psoriasis. J Immunol 184: 5263-5270.

Hagenbaugh A, Sharma S, Dubinett SM, Wei SH, Aranda R, Cheroutre H, Fowell DJ, Binder S, Tsao B, Locksley RM, et al. 1997. Altered immune responses in interleukin 10 transgenic mice. J Exp Med 185: 2101-2110.

Hanash AM, Dudakov JA, Hua G, O'Connor MH, Young LF, Singer NV, West ML, Jenq RR, Holland AM, Kappel LW, et al. 2012. Interleukin-22 protects intestinal stem cells from immune-mediated tissue damage and regulates sensitivity to graft versus host disease. Immunity 37: 339-350.

Hanauer SB, Feagan BG, Lichtenstein GR, Mayer LF, Schreiber S, Colombel JF, Rachmilewitz D, Wolf DC, Olson A, Bao W, et al. 2002. Maintenance infliximab for Crohn's disease: The ACCENT I randomised trial. Lancet 359: 1541-1549.

Hanauer SB, Sandborn WJ, Rutgeerts P, Fedorak RN, Lukas M, MacIntosh D, Panaccione R, Wolf D, Pollack P. 2006. Human anti-tumor necrosis factor monoclonal antibody (adalimumab) in Crohn's disease: The CLASSIC-I trial. Gastroenterology 130: 323-33; quiz 591.

He M, Liang P. 2010. IL-24 transgenic mice: In vivo evidence of overlapping functions for IL-20, IL-22, and IL-24 in the epidermis. J Immunol 184: 1793-1798.

Hill T, Krougly O, Nikoopour E, Bellemore S, Lee-Chan E, Fouser LA, Hill DJ, Singh B. 2013. The involvement of interleukin-22 in the expression of pancreatic $\beta$ cell regenerative Reg genes. Cell Regen (Lond) 2: 2 .

Hou W, Wang X, Ye L, Zhou L, Yang Z-Q, Riedel E, Ho WZ. 2009. Lambda interferon inhibits human immunodeficiency virus type 1 infection of macrophages. J Virol 83: 3834-3842.

Hsu YH, LiHH, Hsieh MY, Liu MF, Huang KY, Chin LS, Chen PC, Cheng HH, Chang MS. 2006. Function of interleukin20 as a proinflammatory molecule in rheumatoid and experimental arthritis. Arthritis Rheum 54: 2722-2733.
Hsu YH, Hsieh PP, Chang MS. 2012. Interleukin-19 blockade attenuates collagen-induced arthritis in rats. Rheumatology (Oxford) 51: 434-442.

Huan C, Kim D, Ou P, Alfonso A, Stanek A. 2016. Mechanisms of interleukin-22's beneficial effects in acute pancreatitis. World J Gastrointest Pathophysiol 7: 108-116.

Huang EH, Park JC, Appelman H, Weinberg AD, Banerjee M, Logsdon CD, Schmidt AM. 2006. Induction of inflammatory bowel disease accelerates adenoma formation in Min +/- mice. Surgery 139: 782-788.

Huber S, Gagliani N, Zenewicz LA, Huber FJ, Bosurgi L, Hu B, Hedl M, Zhang W, O'Connor W, Murphy AJ, et al. 2012. IL-22BP is regulated by the inflammasome and modulates tumorigenesis in the intestine. Nature 491: 259-263.

Huhn RD, Radwanski E, O'Connell SM, Sturgill MG, Clarke L, Cody RP, Affrime MB, Cutler DL. 1996. Pharmacokinetics and immunomodulatory properties of intravenously administered recombinant human interleukin-10 in healthy volunteers. Blood 87: 699-705.

Huhn RD, Radwanski E, Gallo J, Affrime MB, Sabo R, Gonyo G, Monge A, Cutler DL. 1997. Pharmacodynamics of subcutaneous recombinant human interleukin-10 in healthy volunteers. Clin Pharmacol Ther 62: 171-180.

Hunt DWC, Boivin WA, Fairley LA, Jovanovic MM, King DE, Salmon RA, Utting OB. 2006. Ultraviolet B light stimulates interleukin-20 expression by human epithelial keratinocytes. Photochem Photobiol 82: 1292-1300.

Ikeuchi H, Kuroiwa T, Hiramatsu N, Kaneko Y, Hiromura K, Ueki K, Nojima Y. 2005. Expression of interleukin-22 in rheumatoid arthritis: Potential role as a proinflammatory cytokine. Arthritis Rheum 52: 1037-1046.

Innocentin S, Guimarães V, Miyoshi A, Azevedo V, Langella P, Chatel JM, Lefèvre F. 2009. Lactococcus lactis expressing either Staphylococcus aureus fibronectin-binding protein A or Listeria monocytogenes internalin A can efficiently internalize and deliver DNA in human epithelial cells. Appl Environ Microbiol 75: 4870-4878.

Itoh K, Hirohata S. 1995. The role of IL-10 in human B cell activation, proliferation, and differentiation. J Immunol 154: 4341-4350.

Järnerot G, Hertervig E, Friis-Liby I, Blomquist L, Karlén P, Grännö C, Vilien M, Ström M, Danielsson A, Verbaan H, et al. 2005. Infliximab as rescue therapy in severe to moderately severe ulcerative colitis: A randomized, placebocontrolled study. Gastroenterology 128: 1805-1811.

Jeffcoate WJ, Harding KG. 2003. Diabetic foot ulcers. Lancet 361: 1545-1551.

Jiang H, Lin JJ, Su ZZ, Goldstein NI, Fisher PB. 1995. Subtraction hybridization identifies a novel melanoma differentiation associated gene, $m d a-7$, modulated during human melanoma differentiation, growth and progression. Oncogene 11: 2477-2486.

Jiang H, Su ZZ, Lin JJ, Goldstein NI, Young CS, Fisher PB. 1996. The melanoma differentiation associated gene mda-7 suppresses cancer cell growth. Proc Natl Acad Sci 93: 9160-9165.

Jiang R, Wang H, Deng L, Hou J, Shi R, Yao M, Gao Y, Yao A, Wang X, Yu L, et al. 2013. IL-22 is related to development of human colon cancer by activation of STAT3. BMC Cancer 13: 59. 
Justa S, Zhou X, Sarkar S. 2014. Endogenous IL-22 plays a dual role in arthritis: Regulation of established arthritis via IFN- $\gamma$ responses. PloS ONE 9: e93279.

Kagami S, Rizzo HL, Lee JJ, Koguchi Y, Blauvelt A. 2010. Circulating Th17, Th22, and Th1 cells are increased in psoriasis. J Invest Dermatol 130: 1373-1383.

Kamanaka M, Huber S, Zenewicz LA, Gagliani N, Rathinam C, O'Connor W, Wan YY, Nakae S, Iwakura Y, Hao L, et al. 2011. Memory/effector $\left(\mathrm{CD} 45 \mathrm{RB}^{\mathrm{lo}}\right) \mathrm{CD} 4 \mathrm{~T}$ cells are controlled directly by IL-10 and cause IL-22-dependent intestinal pathology. J Exp Med 208: 1027-1040.

Kasama T, Strieter RM, Lukacs NW, Burdick MD, Kunkel SL. 1994. Regulation of neutrophil-derived chemokine expression by IL-10. J Immunol 152: 3559-3569.

Kaser A, Zeissig S, Blumberg RS. 2010. Inflammatory bowel disease. Annu Rev Immunol 28: 573-621.

Ki SH, Park O, Zheng M, Morales-Ibanez O, Kolls JK, Bataller R, Gao B. 2010. Interleukin-22 treatment ameliorates alcoholic liver injury in a murine model of chronic-binge ethanol feeding: Role of signal transducer and activator of transcription 3. Hepatology 52: 1291-1300.

Kirchberger S, Royston DJ, Boulard O, Thornton E, Franchini F, Szabady RL, Harrison O, Powrie F. 2013. Innate lymphoid cells sustain colon cancer through production of interleukin-22 in a mouse model. J Exp Med 210: 917931.

Kobold S, Völk S, Clauditz T, Küpper NJ, Minner S, Tufman A, Düwell P, Lindner M, Koch I, Heidegger S, et al. 2013. Interleukin-22 is frequently expressed in small- and largecell lung cancer and promotes growth in chemotherapyresistant cancer cells. J Thorac Oncol 8: 1032-1042.

Koenig KF, Groeschl I, Pesickova SS, Tesar V, Eisenberger U, Trendelenburg M. 2012. Serum cytokine profile in patients with active lupus nephritis. Cytokine 60: 410-416.

Kofoed K, Skov L, Zachariae C. 2015. New drugs and treatment targets in psoriasis. Acta Derm Venereol 95: 133-139.

Kolumam G, Wu X, Lee WP, Hackney JA, Zavala-Solorio J, Gandham V, Danilenko DM, Arora P, Wang X, Ouyang W. 2017. IL-22R ligands IL-20, IL-22, and IL-24 promote wound healing in diabetic $\mathrm{db} / \mathrm{db}$ mice. PloS ONE 12: e0170639.

Konya V, Mjösberg J. 2015. Innate lymphoid cells in graftversus-host disease. Am J Transplant 15: 2795-2801.

Kopp T, Lenz P, Bello-Fernandez C, Kastelein RA, Kupper TS, Stingl G. 2003. IL-23 production by cosecretion of endogenous p19 and transgenic p40 in keratin 14/p40 transgenic mice: Evidence for enhanced cutaneous immunity. J Immunol 170: 5438-5444.

Kotenko SV, Gallagher G, Baurin VV, Lewis-Antes A, Shen M, Shah NK, Langer JA, Sheikh F, Dickensheets H, Donnelly RP. 2003. IFN- $\lambda$ s mediate antiviral protection through a distinct class II cytokine receptor complex. Nat Immunol 4: 69-77.

Kragstrup TW, Otkjaer K, Holm C, Jørgensen A, Hokland M, Iversen L, Deleuran B. 2008. The expression of IL-20 and IL-24 and their shared receptors are increased in rheumatoid arthritis and spondyloarthropathy. Cytokine 41: 16-23.

Kreis S, Philippidou D, Margue C, Rolvering C, Haan C, Dumoutier L, Renauld JC, Behrmann I. 2007. Recombi- nant interleukin-24 lacks apoptosis-inducing properties in melanoma cells. PloS ONE 2: e1300.

Kreis S, Philippidou D, Margue C, Behrmann I. 2008. IL-24: A classic cytokine and/or a potential cure for cancer? J Cell Mol Med 12: 2505-2510.

Kühn R, Löhler J, Rennick D, Rajewsky K, Muller W. 1993. Interleukin-10-deficient mice develop chronic enterocolitis. Cell 75: 263-274.

Lasfar A, de laTorre A, Abushahba W, Cohen-Solal KA, Castaneda I, Yuan Y, Reuhl K, Zloza A, Raveche E, Laskin DL, et al. 2016. Concerted action of IFN- $\alpha$ and IFN- $\lambda$ induces local NK cell immunity and halts cancer growth. Oncotarget 7: 49259-49267.

Lauw FN, Pajkrt D, Hack CE, Kurimoto M, van Deventer SJ, van der Poll T. 2000. Proinflammatory effects of IL-10 during human endotoxemia. J Immunol 165: 2783-2789.

Leipe J, Schramm MA, Grunke M, Baeuerle M, Dechant C, Nigg AP, Witt MN, Vielhauer V, Reindl CS, SchulzeKoops $\mathrm{H}$, et al. 2011. Interleukin 22 serum levels are associated with radiographic progression in rheumatoid arthritis. Ann Rheum Dis 70: 1453-1457.

Leung JM, Davenport M, Wolff MJ, Wiens KE, Abidi WM, Poles MA, Cho I, Ullman T, Mayer L, Loke P. 2013. IL-22producing $\mathrm{CD}^{+}$cells are depleted in actively inflamed colitis tissue. Mucosal Immunol 7: 124-133.

Levy Y, Brouet JC. 1994. Interleukin-10 prevents spontaneous death of germinal center B cells by induction of the bcl-2 protein. J Clin Invest 93: 424-428.

Li J, Chen J, Kirsner R. 2007. Pathophysiology of acute wound healing. Clin Dermatol 25: 9-18.

Li W, Lewis-Antes A, Huang J, Balan M, Kotenko SV. 2008. Regulation of apoptosis by type III interferons. Cell Prolif 41: 960-979.

Li W, Danilenko DM, Bunting S, Ganesan R, Sa S, Ferrando R, Wu TD, Kolumam GA, Ouyang W, Kirchhofer D. 2009. The serine protease marapsin is expressed in stratified squamous epithelia and is up-regulated in the hyperproliferative epidermis of psoriasis and regenerating wounds. J Biol Chem 284: 218-228.

Li Q, Kawamura K, Ma G, Iwata F, Numasaki M, Suzuki N, Shimada H, Tagawa M. 2010. Interferon- $\lambda$ induces $G_{1}$ phase arrest or apoptosis in oesophageal carcinoma cells and produces anti-tumour effects in combination with anti-cancer agents. Eur J Cancer 46: 180-190.

Liang SC, Tan XY, Luxenberg DP, Karim R, Dunussi-Joannopoulos K, Collins M, Fouser LA. 2006. Interleukin (IL)22 and IL-17 are coexpressed by Th17 cells and cooperatively enhance expression of antimicrobial peptides. $J$ Exp Med 203: 2271-2279.

Lin FC, Young HA. 2014. Interferons: Success in anti-viral immunotherapy. Cytokine Growth Factor Rev 25: 369376.

Lindemans CA, Calafiore M, Mertelsmann AM, O'Connor MH, Dudakov JA, Jenq RR, Velardi E, Young LF, Smith OM, Lawrence G, et al. 2015. Interleukin-22 promotes intestinal-stem-cell-mediated epithelial regeneration. $\mathrm{Na}$ ture 528: 560-564.

Llorente L, Richaud-Patin Y, García-Padilla C, Claret E, Jakez-Ocampo J, Cardiel MH, Alcocer-Varela J, GrangeotKeros L, Alarcón-Segovia D, Wijdenes J, et al. 2000. Clinical and biologic effects of anti-interleukin-10 monoclo- 
X. Wang et al.

nal antibody administration in systemic lupus erythematosus. Arthritis Rheum 43: 1790-1800.

Loser K, Apelt J, Voskort M, Mohaupt M, Balkow S, Schwarz T, Grabbe S, Beissert S. 2007. IL-10 controls ultravioletinduced carcinogenesis in mice. J Immunol 179: 365-371.

Ma H-L, Liang S, Li J, Napierata L, Brown T, Benoit S, Senices M, Gill D, Dunussi-Joannopoulos K, Collins M, et al. 2008. IL-22 is required for Th17 cell-mediated pathology in a mouse model of psoriasis-like skin inflammation. $J$ Clin Invest 118: 597-607.

Mannino MH, Zhu Z, Xiao H, Bai Q, Wakefield MR, Fang Y 2015. The paradoxical role of IL-10 in immunity and cancer. Cancer Lett 367: 103-107.

Marcello T, Grakoui A, Barba-Spaeth G, Machlin ES, Kotenko SV, MacDonald MR, Rice CM. 2006. Interferons $\alpha$ and $\lambda$ inhibit hepatitis $C$ virus replication with distinct signal transduction and gene regulation kinetics. Gastroenterology 131: 1887-1898.

Marijnissen RJ, Koenders MI, Smeets RL, Stappers MHT, Nickerson-Nutter C, Joosten LAB, Boots AMH, van den Berg WB. 2011. Increased expression of interleukin-22 by synovial Th17 cells during late stages of murine experimental arthritis is controlled by interleukin-1 and enhances bone degradation. Arthritis Rheum 63: 29392948.

Martin R, Chain F, Miquel S, Natividad JM, Sokol H, Verdu EF, Langella P, Bermúdez-Humarán LG. 2014. Effects in the use of a genetically engineered strain of Lactococcus lactis delivering in situ IL-10 as a therapy to treat lowgrade colon inflammation. Hum Vaccin Immunother 10: 1611-1621.

McGee HM, Schmidt BA, Booth CJ, Yancopoulos GD, Valenzuela DM, Murphy AJ, Stevens S, Flavell RA, Horsley V. 2013. IL-22 promotes fibroblast-mediated wound repair in the skin. J Invest Dermatol 133: 1321-1329.

Meager A, Visvalingam K, Dilger P, Bryan D, Wadhwa M. 2005. Biological activity of interleukins-28 and -29: Comparison with type I interferons. Cytokine 31: 109-118.

Michaels J, Churgin SS, Blechman KM, Greives MR, Aarabi S, Galiano RD, Gurtner GC. 2007. db/db mice exhibit severe wound-healing impairments compared with other murine diabetic strains in a silicone-splinted excisional wound model. Wound Repair Regen 15: 665-670.

Miller DM, Klucher KM, Freeman JA, Hausman DF, Fontana D, Williams DE. 2009. Interferon $\lambda$ as a potential new therapeutic for hepatitis C. Ann NY Acad Sci 1182: 80-87.

Miyoshi A, Jamet E, Commissaire J, Renault P, Langella P, Azevedo V. 2004. A xylose-inducible expression system for Lactococcus lactis. FEMS Microbiol Lett 239: 205-212.

Montes-Torres A, Llamas-Velasco M, Pérez-Plaza A, Solano-López G, Sánchez-Pérez J. 2015. Biological treatments in atopic dermatitis. J Clin Med 4: 593-613.

Moore K, de Waal M, Coffman R, O'Garra A. 2001. Interleukin-10 and the interleukin-10 receptor. Annu Rev Immunol 19: 683-765.

Mordstein M, Kochs G, Dumoutier L, Renauld JC, Paludan SR, Klucher K, Staeheli P. 2008. Interferon- $\lambda$ contributes to innate immunity of mice against influenza $A$ virus but not against hepatotropic viruses. PloS Pathog 4: e1000151.

Mordstein M, Neugebauer E, Ditt V, Jessen B, Rieger T, Falcone V, Sorgeloos F, Ehl S, Mayer D, Kochs G, et al.
2010. $\Lambda$ interferon renders epithelial cells of the respiratory and gastrointestinal tracts resistant to viral infections. J Virol 84: 5670-5677.

Motzer RJ, Escudier B, McDermott DF, George S, Hammers HJ, Srinivas S, Tykodi SS, Sosman JA, Procopio G, Plimack ER, et al. 2015. Nivolumab versus everolimus in advanced renal-cell carcinoma. $N$ Engl $J$ Med 373: 1803-1813.

Muir AJ, Arora S, Everson G, Flisiak R, George J, Ghalib R, Gordon SC, Gray T, Greenbloom S, Hassanein T, et al. 2014. A randomized phase $2 \mathrm{~b}$ study of peginterferon $\lambda$-1a for the treatment of chronic HCV infection. J Hepatol 61: $1238-1246$.

Mumm JB, Emmerich J, Zhang X, Chan I, Wu L, Mauze S, Blaisdell S, Basham B, Dai J, Grein J, et al. 2011. IL-10 elicits IFN $\gamma$-dependent tumor immune surveillance. Cancer Cell 20: 781-796.

Munneke JM, Björklund AT, Mjösberg JM, Garming-Legert K, Bernink JH, Blom B, Huisman C, van Oers MHJ, Spits H, Malmberg K-J, et al. 2014. Activated innate lymphoid cells are associated with a reduced susceptibility to graftversus-host disease. Blood 124: 812-821.

Nagelkerken L, Blauw B, Tielemans M. 1997. IL-4 abrogates the inhibitory effect of IL-10 on the development of experimental allergic encephalomyelitis in SJL mice. Int Immunol 9: 1243-1251.

Naing A, Papadopoulos KP, Autio KA, Ott PA, Patel MR, Wong DJ, Falchook GS, Pant S, Whiteside M, Rasco DR, et al. 2016. Safety, antitumor activity, and immune activation of pegylated recombinant human interleukin-10 (AM0010) in patients with advanced solid tumors. $J$ Clin Oncol 34: 3562-3569.

Nemunaitis J, Fong T, Shabe P, Martineau D, Ando D. 2001. Comparison of serum interleukin-10 (IL-10) levels between normal volunteers and patients with advanced melanoma. Cancer Invest 19: 239-247.

Nestle FO, Kaplan DH, Barker J. 2009. Psoriasis. N Engl J Med 361: 496-509.

Nograles KE, Zaba LC, Shemer A, Fuentes-Duculan J, Cardinale I, Kikuchi T, Ramon M, Bergman R, Krueger JG, Guttman-Yassky E. 2009. IL-22-producing "T22" T cells account for upregulated IL-22 in atopic dermatitis despite reduced IL-17-producing TH17 T cells. J Allergy Clin Immunol 123: 1244-1252.e2.

Numasaki M, Tagawa M, Iwata F, Suzuki T, Nakamura A, Okada M, Iwakura Y, Aiba S, Yamaya M. 2007. IL-28 elicits antitumor responses against murine fibrosarcoma. J Immunol 178: 5086-5098.

O'Garra A, Barrat FJ, Castro AG, Vicari A, Hawrylowicz C. 2008. Strategies for use of IL-10 or its antagonists in human disease. Immunol Rev 223: 114-131.

Onoguchi K, Yoneyama M, Takemura A, Akira S, Taniguchi T, Namiki H, Fujita T. 2007. Viral infections activate types I and III interferon genes through a common mechanism. J Biol Chem 282: 7576-7581.

O'Shea JJ, Kanno Y, Chan AC. 2014. In search of magic bullets: The golden age of immunotherapeutics. Cell 157: 227-240.

Ota N, Wong K, Valdez PA, Zheng Y, Crellin NK, Diehl L, Ouyang W. 2011. IL-22 bridges the lymphotoxin pathway with the maintenance of colonic lymphoid structures 
Targeting IL-10 Family Cytokines to Treat Diseases

during infection with Citrobacter rodentium. Nat Immunol 12: 941-948.

Otkjaer K, Kragballe K, Funding AT, Clausen JT, Noerby PL, Steiniche T, Iversen L. 2005. The dynamics of gene expression of interleukin-19 and interleukin-20 and their receptors in psoriasis. Br J Dermatol 153: 911-918.

Ouyang W. 2010. Distinct roles of IL-22 in human psoriasis and inflammatory bowel disease. Cytokine Growth Factor Rev 21: 435-441.

Ouyang W, Rutz S, Crellin NK, Valdez PA, Hymowitz SG. 2011. Regulation and functions of the IL-10 family of cytokines in inflammation and disease. Anпu Rev Immunol 29: 71-109.

Pan H, Hong F, Radaeva S, Gao B. 2004. Hydrodynamic gene delivery of interleukin-22 protects the mouse liver from concanavalin A-, carbon tetrachloride-, and Fas ligandinduced injury via activation of STAT3. Cell Mol Immunol 1: 43-49.

Park O, Wang H, Weng H, Feigenbaum L, Li H, Yin S, Ki SH, Yoo SH, Dooley S, Wang FS, et al. 2011. In vivo consequences of liver-specific interleukin-22 expression: Implications for human liver disease progression. Hepatology 54: 252-261.

Park H, Serti E, Eke O, Muchmore B, Prokunina-Olsson L, Capone S, Folgori A, Rehermann B. 2012. IL-29 is the dominant type III interferon produced by hepatocytes during acute hepatitis $C$ virus infection. Hepatology 56: 2060-2070.

Pelczar P, Witkowski M, Perez LG, Kempski J, Hammel AG, Brockmann L, Kleinschmidt D, Wende S, Haueis C, Bedke T, et al. 2016. A pathogenic role for T cell-derived IL-22BP in inflammatory bowel disease. Science 354: 358-362.

Pène J, Chevalier S, Preisser L, Vénéreau E, Guilleux MH, Ghannam S, Molès JP, Danger Y, Ravon E, Lesaux S, et al. 2008. Chronically inflamed human tissues are infiltrated by highly differentiated Th17 lymphocytes. J Immunol 180: $7423-7430$.

Perera GK, Ainali C, Semenova E, Hundhausen C, Barinaga G, Kassen D, Williams AE, Mirza MM, Balazs M, Wang $\mathrm{X}$, et al. 2014. Integrative biology approach identifies cytokine targeting strategies for psoriasis. Sci Transl Med 6: 223ra22.

Pestka S, Krause CD, Sarkar D, Walter MR, Shi Y, Fisher PB. 2004. Interleukin-10 and related cytokines and receptors. Annu Rev Immunol 22: 929-979.

Pickert G, Neufert C, Leppkes M, Zheng Y, Wittkopf N, Warntjen M, Lehr HA, Hirth S, Weigmann B, Wirtz S, et al. 2009. STAT3 links IL-22 signaling in intestinal epithelial cells to mucosal wound healing. J Exp Med 206: 1465-1472.

Radaeva S, Sun R, Pan HN, Hong F, Gao B. 2004. Interleukin 22 (IL-22) plays a protective role in T cell-mediated murine hepatitis: IL-22 is a survival factor for hepatocytes via STAT3 activation. Hepatology 39: 1332-1342.

Robert C, Schachter J, Long GV, Arance A, Grob JJ, Mortier L, Daud A, Carlino MS, McNeil C, Lotem M, et al. 2015. Pembrolizumab versus ipilimumab in advanced melanoma. N Engl J Med 372: 2521-2532.

Rømer J, Hasselager E, Nørby PL, Steiniche T, Thorn Clausen J, Kragballe K. 2003. Epidermal overexpression of interleukin-19 and -20 mRNA in psoriatic skin disap- pears after short-term treatment with cyclosporine a or calcipotriol. J Invest Dermatol 121: 1306-1311.

Rosenblum IY, Johnson RC, Schmahai TJ. 2002. Preclinical safety evaluation of recombinant human interleukin-10. Regul Toxicol Pharmacol 35: 56-71.

Rousset F, Garcia E, Defrance T, Péronne C, Vezzio N, Hsu DH, Kastelein R, Moore KW, Banchereau J. 1992. Interleukin 10 is a potent growth and differentiation factor for activated human B lymphocytes. Proc Natl Acad Sci 89: 1890-1893.

Rousset F, Peyrol S, Garcia E, Vezzio N, Andujar M, Grimaud JA, Banchereau J. 1995. Long-term cultured CD40activated B lymphocytes differentiate into plasma cells in response to IL-10 but not IL-4. Int Immunol 7: 12431253.

Ruffell B, Chang-Strachan D, Chan V, Rosenbusch A, Ho CMT, Pryer N, Daniel D, Hwang ES, Rugo HS, Coussens LM. 2014. Macrophage IL-10 blocks CD8 ${ }^{+} \mathrm{T}$ cell-dependent responses to chemotherapy by suppressing IL-12 expression in intratumoral dendritic cells. Cancer Cell 26: 623-637.

Rutz S, Ouyang W. 2011. Regulation of interleukin-10 and interleukin-22 expression in T helper cells. Curr Opin Immunol 23: 605-612.

Rutz S, Ouyang W. 2016. Regulation of interleukin-10 expression. Adv Exp Med Biol 941: 89-116.

Rutz S, Noubade R, Eidenschenk C, Ota N, Zeng W, Zheng Y, Hackney J, Ding J, Singh H, Ouyang W. 2011. Transcription factor c-Maf mediates the TGF- $\beta$-dependent suppression of IL-22 production in $\mathrm{T}_{\mathrm{H}} 17$ cells. Nat Immunol 12: 1238-1245.

Rutz S, Eidenschenk C, Ouyang W. 2013. IL-22, not simply a Th17 cytokine. Immunol Rev 252: 116-132.

Rutz S, Wang X, Ouyang W. 2014. The IL-20 subfamily of cytokines-From host defence to tissue homeostasis. Nat Rev Immunol 14: 783-795.

Sa SM, Valdez PA, Wu J, Jung K, Zhong F, Hall L, Kasman I, Winer J, Modrusan Z, Danilenko DM, et al. 2007. The effects of IL-20 subfamily cytokines on reconstituted human epidermis suggest potential roles in cutaneous innate defense and pathogenic adaptive immunity in psoriasis. $J$ Immunol 178: 2229-2240.

Sabat R, Ouyang W, Wolk K. 2013. Therapeutic opportunities of the IL-22-IL-22R1 system. Nat Rev Drug Discov 13: 21-38.

Sakurai N, Kuroiwa T, Ikeuchi H, Hiramatsu N, Maeshima A, Kaneko Y, Hiromura K, Nojima Y. 2008. Expression of IL-19 and its receptors in RA: Potential role for synovial hyperplasia formation. Rheumatology (Oxford) 47: 815820.

Sandborn WJ, Feagan BG, Stoinov S, Honiball PJ, Rutgeerts P, Mason D, Bloomfield R, Schreiber S, PRECISE 1 Study Investigators. 2007. Certolizumab pegol for the treatment of Crohn's disease. N Engl J Med 357: 228-238.

Sandborn WJ, Feagan BG, Fedorak RN, Scherl E, Fleisher MR, Katz S, Johanns J, Blank M, Rutgeerts P, Ustekinumab Crohn's Disease Study. 2008. A randomized trial of Ustekinumab, a human interleukin-12/23 monoclonal antibody, in patients with moderate-to-severe Crohn's disease. Gastroenterology 135: 1130-1141. 
X. Wang et al.

Saraiva M, O'Garra A. 2010. The regulation of IL-10 production by immune cells. Nat Rev Immunol 10: 170-181.

Sato A, Ohtsuki M, Hata M, Kobayashi E, Murakami T. 2006 Antitumor activity of IFN- $\lambda$ in murine tumor models. $J$ Immunol 176: 7686-7694.

Sauane M, Gopalkrishnan RV, Sarkar D, Su ZZ, Lebedeva IV, Dent P, Pestka S, Fisher PB. 2003. MDA-7/IL-24: Novel cancer growth suppressing and apoptosis inducing cytokine. Cytokine Growth Factor Rev 14: 35-51.

Saxena A, Khosraviani S, Noel S, Mohan D, Donner T, Hamad ARA. 2015. Interleukin-10 paradox: A potent immunoregulatory cytokine that has been difficult to harness for immunotherapy. Cytokine 74: 27-34.

Schreiber S, Fedorak RN, Nielsen OH, Wild G, Williams CN, Nikolaus S, Jacyna M, Lashner BA, Gangl A, Rutgeerts P, et al. 2000. Safety and efficacy of recombinant human interleukin 10 in chronic active Crohn's disease. Crohn's Disease IL-10 Cooperative Study Group. Gastroenterology 119: 1461-1472.

Schuetze N, Schoeneberger S, Mueller U, Freudenberg MA, Alber G, Straubinger RK. 2005. IL-12 family members: Differential kinetics of their TLR4-mediated induction by Salmonella enteritidis and the impact of IL-10 in bone marrow-derived macrophages. Int Immunol 17: 649-659.

Schwager K, Kaspar M, Bootz F, Marcolongo R, Paresce E, Neri D, Trachsel E. 2009. Preclinical characterization of DEKAVIL (F8-IL10), a novel clinical-stage immunocytokine which inhibits the progression of collagen-induced arthritis. Arthritis Res Ther 11: R142.

Schwager K, Bootz F, Imesch P, Kaspar M, Trachsel E, Neri D. 2011. The antibody-mediated targeted delivery of interleukin-10 inhibits endometriosis in a syngeneic mouse model. Hum Reprod 26: 2344-2352.

Sellon RK, Tonkonogy S, Schultz M, Dieleman LA, Grenther W, Balish E, Rennick DM, Sartor RB. 1998. Resident enteric bacteria are necessary for development of spontaneous colitis and immune system activation in interleukin10-deficient mice. Infect Immun 66: 5224-5231.

Šenolt L, Leszczynski P, Dokoupilová E, Göthberg M, Valencia X, Hansen BB, Cañete JD. 2015. Efficacy and safety of anti-interleukin-20 monoclonal antibody in patients with rheumatoid arthritis: A randomized phase IIa trial. Arthritis Rheumatol 67: 1438-1448.

Sfikakis PP. 2010. The first decade of biologic TNF antagonists in clinical practice: Lessons learned, unresolved issues and future directions. Curr Dir Autoimmun 11: 180210.

Sharma P, Allison JP. 2015. The future of immune checkpoint therapy. Science 348: 56-61.

Sharma P, Hu-Lieskovan S, Wargo JA, Ribas A. 2017. Primary, adaptive, and acquired resistance to cancer immunotherapy. Cell 168: 707-723.

Shen H, Goodall JC, Hill Gaston JS. 2009. Frequency and phenotype of peripheral blood Th17 cells in ankylosing spondylitis and rheumatoid arthritis. Arthritis Rheum 60: 1647-1656.

Sheppard P, Kindsvogel W, Xu W, Henderson K, Schlutsmeyer S, Whitmore TE, Kuestner R, Garrigues U, Birks C, Roraback J, et al. 2003. IL-28, IL-29 and their class II cytokine receptor IL-28R. Nat Immunol 4: 63-68.
Shim JO, Hwang S, Yang HR, Moon JS, Chang JY, Ko JS, Park SS, Kang GH, Kim WS, Seo JK. 2013. Interleukin-10 receptor mutations in children with neonatal-onset Crohn's disease and intractable ulcerating enterocolitis. Eur J Gastroenterol Hepatol 25: 1235-1240.

Singer AJ, Clark RA. 1999. Cutaneous wound healing. $N$ Engl J Med 341: 738-746.

Sommereyns C, Paul S, Staeheli P, Michiels T. 2008. IFNlambda (IFN- $\lambda$ ) is expressed in a tissue-dependent fashion and primarily acts on epithelial cells in vivo. PloS Pathog 4: e1000017.

Sonnenberg GF, Fouser LA, Artis D. 2011. Border patrol: Regulation of immunity, inflammation and tissue homeostasis at barrier surfaces by IL-22. Nat Immunol 12: 383390.

Sosman JA, Verma A, Moss S, Sorokin P, Blend M, Bradlow B, Chachlani N, Cutler D, Sabo R, Nelson M, et al. 2000. Interleukin 10-induced thrombocytopenia in normal healthy adult volunteers: Evidence for decreased platelet production. Br J Haematol 111: 104-111.

Steen HC, Gamero AM. 2010. Interferon- $\lambda$ as a potential therapeutic agent in cancer treatment. J Interferon Cytokine Res 30: 597-602.

Steidler L, Hans W, Schotte L, Neirynck S, Obermeier F, Falk W, Fiers W, Remaut E. 2000. Treatment of murine colitis by Lactococcus lactis secreting interleukin-10. Science 289: 1352-1355.

Steidler L, Neirynck S, Huyghebaert N, Snoeck V, Vermeire A, Goddeeris B, Cox E, Remon JP, Remaut E. 2003. Biological containment of genetically modified Lactococcus lactis for intestinal delivery of human interleukin 10. Nat Biotechnol 21: 785-789.

Steinbrink K, Jonuleit H, Müller G, Schuler G, Knop J, Enk AH. 1999. Interleukin-10-treated human dendritic cells induce a melanoma-antigen-specific anergy in $\mathrm{CD}^{+} \mathrm{T}$ cells resulting in a failure to lyse tumor cells. Blood 93: 1634-1642.

Stenderup K, Rosada C, Worsaae A, Dagnaes-Hansen F, Steiniche T, Hasselager E, Iversen LF, Zahn S, Wöldike H, Holmberg HL, et al. 2009. Interleukin-20 plays a critical role in maintenance and development of psoriasis in the human xenograft transplantation model. Br J Dermatol 160: 284-296.

Sturlan S, Oberhuber G, Beinhauer BG, Tichy B, Kappel S, Wang J, Rogy MA. 2001. Interleukin-10-deficient mice and inflammatory bowel disease associated cancer development. Carcinogenesis 22: 665-671.

Su ZZ, Madireddi MT, Lin JJ, Young CS, Kitada S, Reed JC, Goldstein NI, Fisher PB. 1998. The cancer growth suppressor gene $m d a-7$ selectively induces apoptosis in human breast cancer cells and inhibits tumor growth in nude mice. Proc Natl Acad Sci 95: 14400-14405.

Sugimoto K, Ogawa A, Mizoguchi E, Shimomura Y, Andoh A, Bhan AK, Blumberg RS, Xavier RJ, Mizoguchi A. 2008. IL-22 ameliorates intestinal inflammation in a mouse model of ulcerative colitis. J Clin Invest 118: 534-544.

Sun DP, Yeh CH, So E, Wang LY, Wei TS, Chang MS, Hsing CH. 2013. Interleukin (IL)-19 promoted skin wound healing by increasing fibroblast keratinocyte growth factor expression. Cytokine 62: 360-368.

Suppiah V, Moldovan M, Ahlenstiel G, Berg T, Weltman M, Abate ML, Bassendine M, Spengler U, Dore GJ, Powell E, 
et al. 2009. IL28B is associated with response to chronic hepatitis C interferon- $\alpha$ and ribavirin therapy. Nat Genet 41: 1100-1104.

Tanaka Y, Nishida N, Sugiyama M, Kurosaki M, Matsuura K, Sakamoto N, Nakagawa M, Korenaga M, Hino K, Hige S, et al. 2009. Genome-wide association of IL28B with response to pegylated interferon- $\alpha$ and ribavirin therapy for chronic hepatitis C. Nat Genet 41: 1105-1109.

Thomas DL, Thio CL, Martin MP, Qi Y, Ge D, O'Huigin C, Kidd J, Kidd K, Khakoo SI, Alexander G, et al. 2009. Genetic variation in IL28B and spontaneous clearance of hepatitis C virus. Nature 461: 798-801.

Thomas E, Gonzalez VD, Li Q, Modi AA, Chen W, Noureddin M, Rotman Y, Liang TJ. 2012. HCV infection induces a unique hepatic innate immune response associated with robust production of type III interferons. Gastroenterology 142: 978-988.

Tilg H, Van Montfrans C, van den Ende A, Kaser A, van Deventer SJH, Schreiber S, Gregor M, Ludwiczek O, Rutgeerts P, Gasche C, et al. 2002. Treatment of Crohn's disease with recombinant human interleukin 10 induces the proinflammatory cytokine interferon $\gamma$. Gut 50: 191195.

Tohyama M, Hanakawa Y, Shirakata Y, Dai X, Yang L, Hirakawa S, Tokumaru S, Okazaki H, Sayama K, Hashimoto K. 2009. IL-17 and IL-22 mediate IL-20 subfamily cytokine production in cultured keratinocytes via increased IL-22 receptor expression. Eur J Immunol 39: 2779-2788.

Tong AW, Nemunaitis J, Su D, Zhang Y, Cunningham C, Senzer N, Netto G, Rich D, Mhashilkar A, Parker K, et al. 2005. Intratumoral injection of INGN 241, a nonreplicating adenovector expressing the melanoma-differentiation associated gene-7 (mda-7/IL24): Biologic outcome in advanced cancer patients. Mol Ther 11: 160-172.

Topalian SL, Hodi FS, Brahmer JR, Gettinger SN, Smith DC, McDermott DF, Powderly JD, Carvajal RD, Sosman JA, Atkins MB, et al. 2012. Safety, activity, and immune correlates of anti-PD-1 antibody in cancer. N Engl J Med 366: 2443-2454.

Topalian SL, Drake CG, Pardoll DM. 2015. Immune checkpoint blockade: A common denominator approach to cancer therapy. Cancer Cell 27: 450-461.

Trachsel E, Bootz F, Silacci M, Kaspar M, Kosmehl H, Neri D. 2007. Antibody-mediated delivery of IL-10 inhibits the progression of established collagen-induced arthritis. Arthritis Res Ther 9: R9.

Uzé G, Monneron D. 2007. IL-28 and IL-29: Newcomers to the interferon family. Biochimie 89: 729-734.

van Deventer SJ, Elson CO, Fedorak RN; Crohn's Disease Study Group. 1997. Multiple doses of intravenous interleukin 10 in steroid-refractory Crohn's disease. Gastroenterology 113: 383-389.

Vicari AP, Trinchieri G. 2004. Interleukin-10 in viral diseases and cancer: Exiting the labyrinth? Immunol Rev 202 223-236.

Wang Z, Yang L, Jiang Y, Ling ZQ, Li Z, Cheng Y, Huang H, Wang L, Pan Y, Wang Z, et al. 2011. High fat diet induces formation of spontaneous liposarcoma in mouse adipose tissue with overexpression of interleukin 22. PloS ONE 6: e23737.

Wang X, Ota N, Manzanillo P, Kates L, Zavala-Solorio J, Eidenschenk C, Zhang J, Lesch J, Lee WP, Ross J, et al.
2014. Interleukin-22 alleviates metabolic disorders and restores mucosal immunity in diabetes. Nature 514: 237-241.

Weiss G, Bogdan C, Hentze MW. 1997. Pathways for the regulation of macrophage iron metabolism by the antiinflammatory cytokines IL-4 and IL-13. J Immunol 158: $420-425$.

Whitaker EL, Filippov VA, Duerksen-Hughes PJ. 2012. Interleukin 24: Mechanisms and therapeutic potential of an anti-cancer gene. Cytokine Growth Factor Rev 23: 323331.

Willems F, Marchant A, Delville JP, Gerard C, Delvaux A, Velu T, de Boer M, Goldman M. 1994. Interleukin-10 inhibits B7 and intercellular adhesion molecule-1 expression on human monocytes. Eur J Immunol 24: $1007-$ 1009.

Williams HC. 2005. Clinical practice. Atopic dermatitis. $N$ Engl J Med 352: 2314-2324.

Wingard JR, Majhail NS, Brazauskas R, Wang Z, Sobocinski KA, Jacobsohn D, Sorror ML, Horowitz MM, Bolwell B, Rizzo JD, et al. 2011. Long-term survival and late deaths after allogeneic hematopoietic cell transplantation. J Clin Oncol 29: 2230-2239.

Witte K, Gruetz G, Volk H-D, Looman AC, Asadullah K, Sterry W, Sabat R, Wolk K. 2009. Despite IFN- $\lambda$ receptor expression, blood immune cells, but not keratinocytes or melanocytes, have an impaired response to type III interferons: Implications for therapeutic applications of these cytokines. Genes Immun 10: 702-714.

Wogensen L, Lee MS, Sarvetnick N. 1994. Production of interleukin 10 by islet cells accelerates immune-mediated destruction of $\beta$ cells in nonobese diabetic mice. J Exp Med 179: 1379-1384.

Wolk K, Sabat R. 2006. Interleukin-22: A novel T- and NKcell derived cytokine that regulates the biology of tissue cells. Cytokine Growth Factor Rev 17: 367-380.

Wolk K, Kunz S, Asadullah K, Sabat R. 2002. Cutting edge: Immune cells as sources and targets of the IL-10 family members? J Immunol 168: 5397-5402.

Wolk K, Kunz S, Witte E, Friedrich M, Asadullah K, Sabat R. 2004. IL-22 increases the innate immunity of tissues. Immunity 21: 241-254.

Wolk K, Witte E, Wallace E, Döcke WD, Kunz S, Asadullah K, Volk HD, Sterry W, Sabat R. 2006. IL-22 regulates the expression of genes responsible for antimicrobial defense, cellular differentiation, and mobility in keratinocytes: A potential role in psoriasis. Eur J Immunol 36: 1309-1323.

Wolk K, Haugen HS, Xu W, Witte E, Waggie K, Anderson M, Baur Vom E, Witte K, Warszawska K, Philipp S, et al. 2009a. IL-22 and IL-20 are key mediators of the epidermal alterations in psoriasis while IL-17 and IFN- $\lambda$ are not. $J$ Mol Med 87: 523-536.

Wolk K, Witte E, Warszawska K, Schulze-Tanzil G, Witte K, Philipp S, Kunz S, Döcke WD, Asadullah K, Volk HD, et al. 2009b. The Th17 cytokine IL-22 induces IL-20 production in keratinocytes: A novel immunological cascade with potential relevance in psoriasis. Eur J Immunol 39: 3570-3581.

Xavier RJ, Podolsky DK. 2007. Unravelling the pathogenesis of inflammatory bowel disease. Nature 448: 427-434. 
X. Wang et al.

Xie MH, Aggarwal S, Ho WH, Foster J, Zhang Z, Stinson J, Wood WI, Goddard AD, Gurney AL. 2000. Interleukin (IL)-22, a novel human cytokine that signals through the interferon receptor-related proteins CRF2-4 and IL-22R. J Biol Chem 275: 31335-31339.

Xing WW, Zou MJ, Liu S, Xu T, Wang JX, Xu DG. 2011. Interleukin-22 protects against acute alcohol-induced hepatotoxicity in mice. Biosci Biotechnol Biochem 75: 1290-1294.

Yen D, Cheung J, Scheerens H, Poulet F, McClanahan T, McKenzie B, Kleinschek MA, Owyang A, Mattson J, Blumenschein W, et al. 2006. IL-23 is essential for T cellmediated colitis and promotes inflammation via IL-17 and IL-6. J Clin Invest 116: 1310-1316.

Yu LZ, Wang HY, Yang SP, Yuan ZP, Xu FY, Sun C, Shi RH. 2013. Expression of interleukin-22/STAT3 signaling pathway in ulcerative colitis and related carcinogenesis. World J Gastroenterol 19: 2638-2649.

Yu H, Lee H, Herrmann A, Buettner R, Jove R. 2014. Revisiting STAT3 signalling in cancer: New and unexpected biological functions. Nat Rev Cancer 14: 736-746.

Zenewicz LA, Yancopoulos GD, Valenzuela DM, Murphy AJ, Karow M, Flavell RA. 2007. Interleukin-22 but not interleukin-17 provides protection to hepatocytes during acute liver inflammation. Immunity 27: 647-659.

Zenewicz LA, Yancopoulos GD, Valenzuela DM, Murphy AJ, Stevens S, Flavell RA. 2008. Innate and adaptive interleukin-22 protects mice from inflammatory bowel disease. Immunity 29: 947-957.

Zenewicz LA, Yin X, Wang G, Elinav E, Hao L, Zhao L, Flavell RA. 2013. IL-22 deficiency alters colonic microbiota to be transmissible and colitogenic. J Immunol 190: 5306-5312.

Zhang L, Li JM, Liu XG, Ma DX, Hu NW, Li YG, Li W, Hu Y, Yu S, Qu X, et al. 2011. Elevated Th22 cells correlated with
Th17 cells in patients with rheumatoid arthritis. J Clin Immunol 31: 606-614.

Zhang L, Li Y-G, Li Y-H, Qi L, Liu X-G, Yuan C-Z, Hu N-W, Ma D-X, Li Z-F, Yang Q, et al. 2012. Increased frequencies of Th22 cells as well as Th17 cells in the peripheral blood of patients with ankylosing spondylitis and rheumatoid arthritis. PloS ONE 7: e31000.

Zheng XX, Steele AW, Hancock WW, Stevens AC, Nickerson PW, Roy-Chaudhury P, Tian Y, Strom TB. 1997. A noncytolytic IL-10/Fc fusion protein prevents diabetes, blocks autoimmunity, and promotes suppressor phenomena in NOD mice. J Immunol 158: 4507-4513.

Zheng Y, Danilenko DM, Valdez P, Kasman I, EasthamAnderson J, Wu J, Ouyang W. 2007. Interleukin-22, a $\mathrm{T}_{\mathrm{H}} 17$ cytokine, mediates IL-23-induced dermal inflammation and acanthosis. Nature 445: 648-651.

Zheng Y, Valdez PA, Danilenko DM, Hu Y, Sa SM, Gong Q, Abbas AR, Modrusan Z, Ghilardi N, de Sauvage FJ, et al. 2008. Interleukin- 22 mediates early host defense against attaching and effacing bacterial pathogens. Nat Med 14: 282-289.

Zhuang Y, Peng LS, Zhao YL, Shi Y, Mao XH, Guo G, Chen W, Liu XF, Zhang JY, Liu T, et al. 2012. Increased intratumoral IL-22-producing $\mathrm{CD}^{+}{ }^{+} \mathrm{T}$ cells and Th22 cells correlate with gastric cancer progression and predict poor patient survival. Cancer Immunol Immunother 61: 1965-1975.

Zitzmann K, Brand S, Baehs S, Göke B, Meinecke J, Spöttl G, Meyer H, Auernhammer CJ. 2006. Novel interferon- $\lambda$ s induce antiproliferative effects in neuroendocrine tumor cells. Biochem Biophys Res Commun 344: 1334-1341.

Zurita-Turk M, del Carmen S, Santos ACG, Pereira VB, Cara DC, Leclercq SY, de LeBlanc AD, Azevedo V, Chatel JM, LeBlanc JG, et al. 2014. Lactococcus lactis carrying the pValac DNA expression vector coding for IL-10 reduces inflammation in a murine model of experimental colitis. BMC Biotechnol 14: 73. 


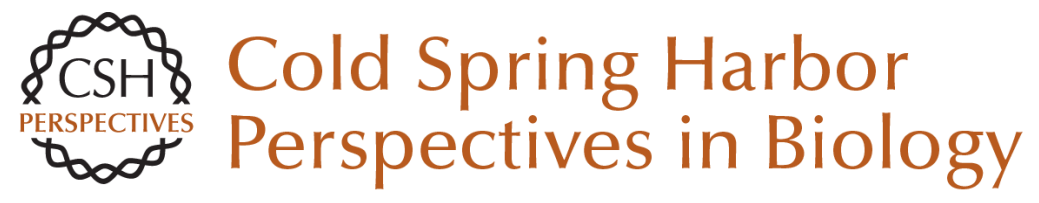

\section{Targeting IL-10 Family Cytokines for the Treatment of Human Diseases}

Xiaoting Wang, Kit Wong, Wenjun Ouyang and Sascha Rutz

Cold Spring Harb Perspect Biol 2019; doi: 10.1101/cshperspect.a028548 originally published online October 16, 2017

\section{Subject Collection Cytokines}

Interleukin (IL)-33 and the IL-1 Family of Cytokines -Regulators of Inflammation and Tissue Homeostasis

Ajithkumar Vasanthakumar and Axel Kallies

Targeting IL-10 Family Cytokines for the Treatment of Human Diseases Xiaoting Wang, Kit Wong, Wenjun Ouyang, et al.

Cytokine-Mediated Regulation of CD8 T-Cell Responses During Acute and Chronic Viral Infection

Masao Hashimoto, Se Jin Im, Koichi Araki, et al.

Cytokines in Cancer Immunotherapy

Thomas A. Waldmann

The Tumor Necrosis Factor Family: Family Conventions and Private Idiosyncrasies David Wallach

The Interferon (IFN) Class of Cytokines and the IFN Regulatory Factor (IRF) Transcription Factor Family

Hideo Negishi, Tadatsugu Taniguchi and Hideyuki Yanai
Interferon $\gamma$ and Its Important Roles in Promoting and Inhibiting Spontaneous and Therapeutic Cancer Immunity

Elise Alspach, Danielle M. Lussier and Robert D. Schreiber

Inflammasome-Dependent Cytokines at the Crossroads of Health and Autoinflammatory Disease

Hanne Van Gorp, Nina Van Opdenbosch and Mohamed Lamkanfi

Innate Lymphoid Cells (ILCs): Cytokine Hubs Regulating Immunity and Tissue Homeostasis Maho Nagasawa, Hergen Spits and Xavier Romero Ros

T Helper Cell Differentiation, Heterogeneity, and

Plasticity Jinfang Zhu

Development, Diversity, and Function of Dendritic Cells in Mouse and Human

David A. Anderson III, Kenneth M. Murphy and Carlos G. Briseño

Cytokines and Long Noncoding RNAs Susan Carpenter and Katherine A. Fitzgerald

For additional articles in this collection, see http://cshperspectives.cshlp.org/cgi/collection/

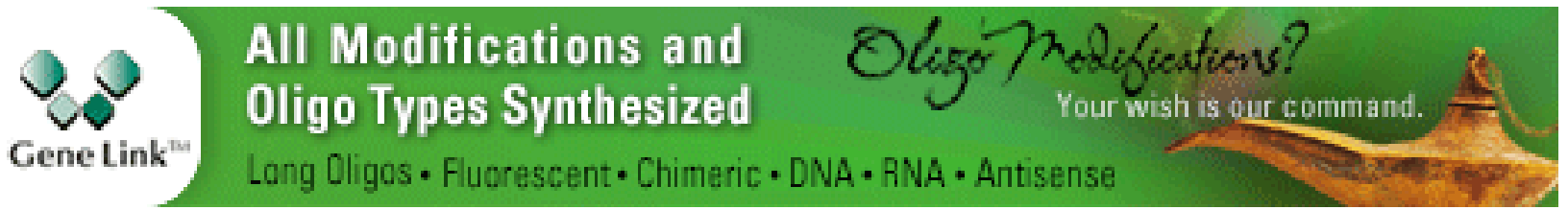


Role of the $\beta$ Common $(\beta \mathrm{c})$ Family of Cytokines in Health and Disease

Timothy R. Hercus, Winnie L. T. Kan, Sophie E. Broughton, et al.

Interleukin (IL)-12 and IL-23 and Their Conflicting Roles in Cancer Juming Yan, Mark J. Smyth and Michele W.L. Teng
Negative Regulation of Cytokine Signaling in Immunity

Akihiko Yoshimura, Minako Ito, Shunsuke Chikuma, et al.

Cancer Inflammation and Cytokines

Maria Rosaria Galdiero, Gianni Marone and Alberto Mantovani

For additional articles in this collection, see http://cshperspectives.cshlp.org/cgi/collection/

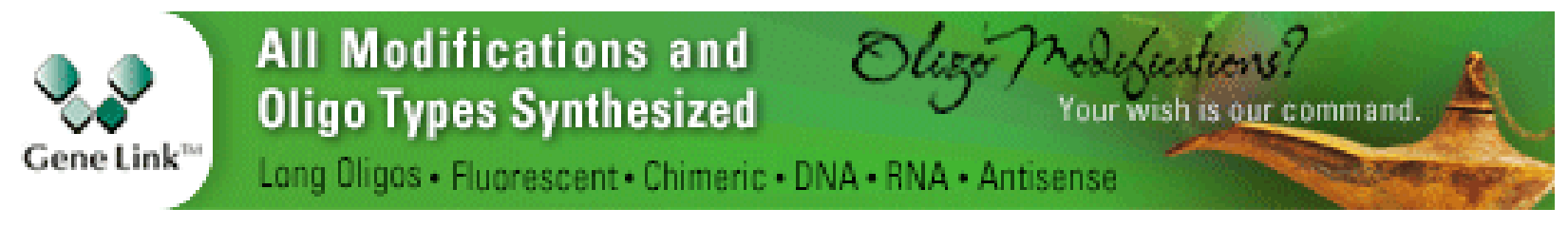

Copyright @ 2019 Cold Spring Harbor Laboratory Press; all rights reserved 